\title{
QUEEN'S
UNIVERSITY
BELFAST
}

\section{Performance Assessment of a Hybrid Photovoltaic-Thermal and Heat Pump System for Solar Heating and Electricity}

Obalanlege, M., Mahmoudi, Y., Douglas, R., Ebrahimnia-Bajestan, E., Davidson, J., \& Bailie, D. (2020). Performance Assessment of a Hybrid Photovoltaic-Thermal and Heat Pump System for Solar Heating and Electricity. Renewable Energy, 48, 558-572. https://doi.org/10.1016/j.renene.2019.10.061

Published in:

Renewable Energy

Document Version:

Peer reviewed version

Queen's University Belfast - Research Portal:

Link to publication record in Queen's University Belfast Research Portal

\section{Publisher rights}

Copyright 2019 Elsevier.

This manuscript is distributed under a Creative Commons Attribution-NonCommercial-NoDerivs License

(https://creativecommons.org/licenses/by-nc-nd/4.0/), which permits distribution and reproduction for non-commercial purposes, provided the author and source are cited.

\section{General rights}

Copyright for the publications made accessible via the Queen's University Belfast Research Portal is retained by the author(s) and / or other copyright owners and it is a condition of accessing these publications that users recognise and abide by the legal requirements associated with these rights.

Take down policy

The Research Portal is Queen's institutional repository that provides access to Queen's research output. Every effort has been made to ensure that content in the Research Portal does not infringe any person's rights, or applicable UK laws. If you discover content in the Research Portal that you believe breaches copyright or violates any law, please contact openaccess@qub.ac.uk. 


\title{
Performance Assessment of a Hybrid Photovoltaic-Thermal and Heat Pump System for Solar Heating and Electricity
}

\author{
Mustapha A. Obalanlege ${ }^{1}$, Yasser Mahmoudi ${ }^{1 *}$, Roy Douglas ${ }^{1}$, \\ Ehsan Ebrahimnia-Bajestan ${ }^{2}$, John Davidson ${ }^{3}$, David Bailie ${ }^{3}$ \\ ${ }^{1}$ School of Mechanical and Aerospace Engineering, Queens University Belfast, Belfast BT9 5AH, UK \\ ${ }^{2}$ Department of Mechanical and Manufacturing Engineering, University of Calgary, Calgary AB T2N 1N4, Canada \\ ${ }^{3}$ BL Refrigeration and Air Conditioning Ltd., Belfast BT3 9LE, UK \\ *Corresponding author: Tel: +44 (0)2890975495, email: s.mahmoudilarimi@qub.ac.uk
}

\section{Abstract}

This work investigates a solar combined heat and power systems based on hybrid photovoltaic-thermal heat pump systems for the simultaneous provision of space heating and electricity to residential homes. The analysed system connects a photovoltaic-thermal (PVT) panel, through a PVT water tank, to a heat pump. The study is based on quasi-steady state heat transfer and thermodynamic analysis that takes incremental time steps to solve for the fluids temperature changes from the heat pump and the solar PVT panels. The effects of solar irradiance, size of the water tank and the water flow rate in the PVT pipes (laminar and turbulent) on the performance of the system are analysed. Particular focus is made towards the efficiency (electrical and thermal) of the PVT and the COP of the heat pump. Results show that the minimum COP of the heat pump is 4.2 , showing the high performance of the proposed hybrid system. Increasing the water flowrate through the PVT panel from $3 \mathrm{~L} / \mathrm{min}$ (laminar) to $17 \mathrm{~L} / \mathrm{min}$ (turbulent) increases the PVT's total efficiency (electrical + thermal) from $61 \%$ to $64.5 \%$. Increasing the size of the PVT water tank from $1 \mathrm{~L}$ to $100 \mathrm{~L}$, increases the total efficiency of the PVT panel by $6.5 \%$.

Keywords: solar photovoltaic-thermal; heat pump; hybrid system; quasi-steady state modelling 


\section{Nomenclature}

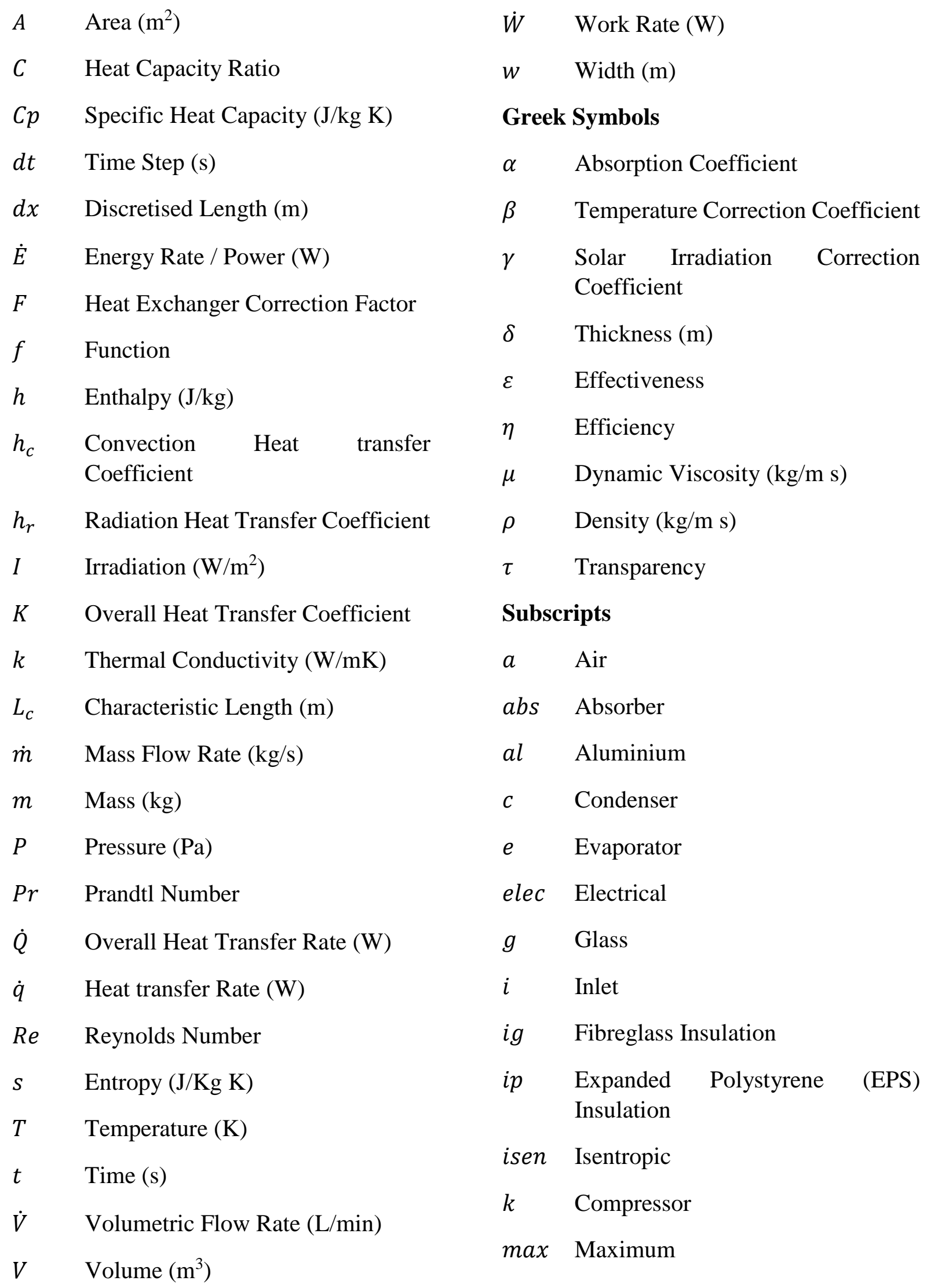




\begin{tabular}{|c|c|c|c|}
\hline mech & Mechanical & $w$ & Water \\
\hline $\min$ & Minimum & & \\
\hline$o$ & Outlet & \multicolumn{2}{|c|}{ Abbreviations } \\
\hline$p v$ & Photovoltaic & $\mathrm{COP}$ & Coefficient of Performance \\
\hline$r$ & Refrigerant & $\mathrm{HP}$ & Heat Pump \\
\hline ref & Reference & LMTD & Log-Mean Temperature Difference \\
\hline$s$ & Sky & NTU & Number of Transfer Units \\
\hline$t$ & tube & $\mathrm{PV}$ & Photovoltaic \\
\hline therm & $\imath$ Thermal & PVT & Photovoltaic-Thermal \\
\hline vol & Volumetric & UK & United Kingdom \\
\hline
\end{tabular}

1 Introduction

2 A change towards the de-carbonisation and diversification of energy sources is taking place 3 globally [1]. The overall movement is towards renewable and sustainable energy, including solar 4 energy [2]. In this regard, solar photovoltaics (PV) are extensively used to generate electricity 5 [3]. However, PV panels are typically $20 \%$ efficient [4]. The rest of the absorbed sunlight rays 6 are converted into heat [4]. The generated heat increases the temperature of the panel, resulting 7 in a decrease in electrical efficiency [5]. This generated heat must be extracted from PV panels 8 to prevent excessive heating of the PV cells. Panels can be actively cooled by passing a fluid 9 through the rear of the panel to extract both heat and electrical power [6]. This combined solar 10 heat and electrical power system is known as a photovoltaic-thermal (PVT) system [3]. The fluid 11 that passes through the PVT panel absorbs the excess heat, reducing the PV temperature [7]. The 12 heated fluid is used for heat related energy consumption (e.g. [5, 8]). Herrando et al. [5, 9] using 13 thermodynamic modelling showed that a PVT system could cover $51 \%$ of the electrical demand 14 and $36 \%$ of the hot water demand for a 3-bedroom house in London, UK. However, the greatest 15 domestic energy consumption is heating [1]. In Europe, buildings consume $60 \%$ of their total 16 energy for heating [1]. The challenge is that the heat energy recovered from the PV panel does 17 not directly produce high enough temperatures to cover the heating demand of a household. One 18 solution to this challenge is to integrate the PV panel with a heat pump [10]. An area of research 19 with this technology is in direct expansion PVT heat pump (DEPVT/HP) systems. This 20 technology involves the direct heating of the heat pump's working fluid by PVT panels, which has been extensively researched in previous numerical (e.g. [10, 11]) and experimental (e.g. [12, $13,14,15])$ studies. A cooled PV based on a DEPVT/HP system can have up to $2 \%$ higher electrical efficiency than the uncooled PV module [12] and can achieve a relatively a high combined coefficient of performance $\left(\mathrm{COP}^{1}\right)$ of $5.6[15]$.

From a practical point of view, installing a DEPVT/HP system on a domestic site can become a health and safety hazard [16]. In homes, solar PVT panels are usually installed on the roof 27 [17]. For a DEPVT/HP system, the heat pump refrigerant will have to circulate outside the heat

\footnotetext{
${ }^{1}$ Combined COP is the ratio of power out of the system relative to power into the system including both thermal and electrical power generation.
} 
pump unit towards the PVT through connecting pipes, and then return to the heat pump unit [18]. The extra piping required would make system installation difficult as the piping needs to meet the sealing standards for refrigerants [18]. This refrigerant piping would experience varying temperatures and pressures as the heat source varies throughout the operation of the heat pump [18]. This may result in possible refrigerant leaks [18], which can present health risks for the occupants [16,19] and can contribute to climate change [20]. These issues make the DEPVT/HP impractical for deployment in domestic applications.

A solution to the problems associated with the DEPVT/HP systems is the utilisation of indirect expansion PVT heat pump (IEPVT/HP) systems [18]. An IEPVT/HP system uses a fluid (e.g. water) to absorb the solar thermal energy from a PVT panel and cycle it to a heat exchanger to transfer heat to a heat pump cycle or store in a water tank $[18,21]$. The water tank acts as a heat source for the heat pump [18, 21]. Besgani et al. [22] conducted an experimental study on a dualsource solar-assisted IEPVT/HP system in Milan, Italy, on a detached prefabricated building. Seven PVT panels and one PV panel were used to compare the two different technologies. The PVTs were cooled using water and transferred to the heat pump via a water-based evaporator. The heat pump also used an air-based evaporator to use air as another heat source. They [22] found that the "water-source" operation of the heat pump outperformed the "air-source" operation by 34\%, and that the water-source heat pump did not require any defrost cycling. It was also observed that the electricity production of the PV and PVT panels were similar [22]. They [22] concluded that their IEPVT/HP system has an average COP of 3 [22]. In another experimental study in Lyngby, Denmark, Dannemand et al. [23] analysed the performance of a solar IEPVT/HP system for nine months. They [23] demonstrated that their system can operate and absorb solar energy at solar radiation intensities greater than $50 \mathrm{~W} / \mathrm{m}^{2}$ and act as an air source heat absorber at solar radiation intensities less than $50 \mathrm{~W} / \mathrm{m}^{2}$ [23]. Though the system was proved to work, the researchers concluded that optimisation of the system is important [23].

In comparison to the DEPVT/HP, research in the IEPVT/HP is sparse. In literature, the majority of research studied the medium and long term (e.g. months) operation of different configurations of IEPVT/HP systems [22, 24, 23, 25]. Additionally, the influence of the system pertinent parameters (variation in the solar irradiation, PVT water flow rate and storage tank) on the response of the system for long-term operation has not been well studied. Thus, the body of knowledge in this area lacks documentation on the short-term changes that occur with intermittent energy sources such as solar energy. Furthermore, the effect of solar energy intermittency on the short-term (e.g. hours) operation of the IEPVT/HP system has not been analysed. Hence, the main objective of the present work is to observe the effects of variation in the solar irradiation, PVT water flow rate and water storage tank volume on the short-term operation of an IEPVT/HP system. Such an analysis enables us to understand the system's response to the transient variations of different parameters affecting the performance of the IEPVT/HP system. Short-term analysis allows us to understand, (i) the influence of the intermittency on the system's electrical and thermal performance [26], (ii) analyse the capability of the system's flexible elements (e.g. water flow rate and storage tank size) to suppress the solar energy intermittency, and (iii) optimise the design of the system's parameters in order to minimise the impact of the intermittency on the long-term operation of the system. This will eventually contribute to a smarter design of control systems for such technologies for domestic applications. Therefore, this study analyses the thermal and electrical performance of an IEPVT/HP system under short-term operation, by analysing the variation of key parameters, which control the performance of a hybrid system, including solar irradiance, water flow rate in the PVT and storage tank size. 


\section{System Configuration}

The system configuration in this work consists of (from right to left) a PVT water loop, a PVT water tank loop, the water-to-water heat pump loop and a heat rejection loop, as shown in Figure 1. The water-to-water heat pump loop consists of an evaporator, compressor, condenser and expansion valve. The heat rejection loop consists of a water tank to supply the condenser, a heat pump condenser, and a forced convection radiator that rejects heat to the user.

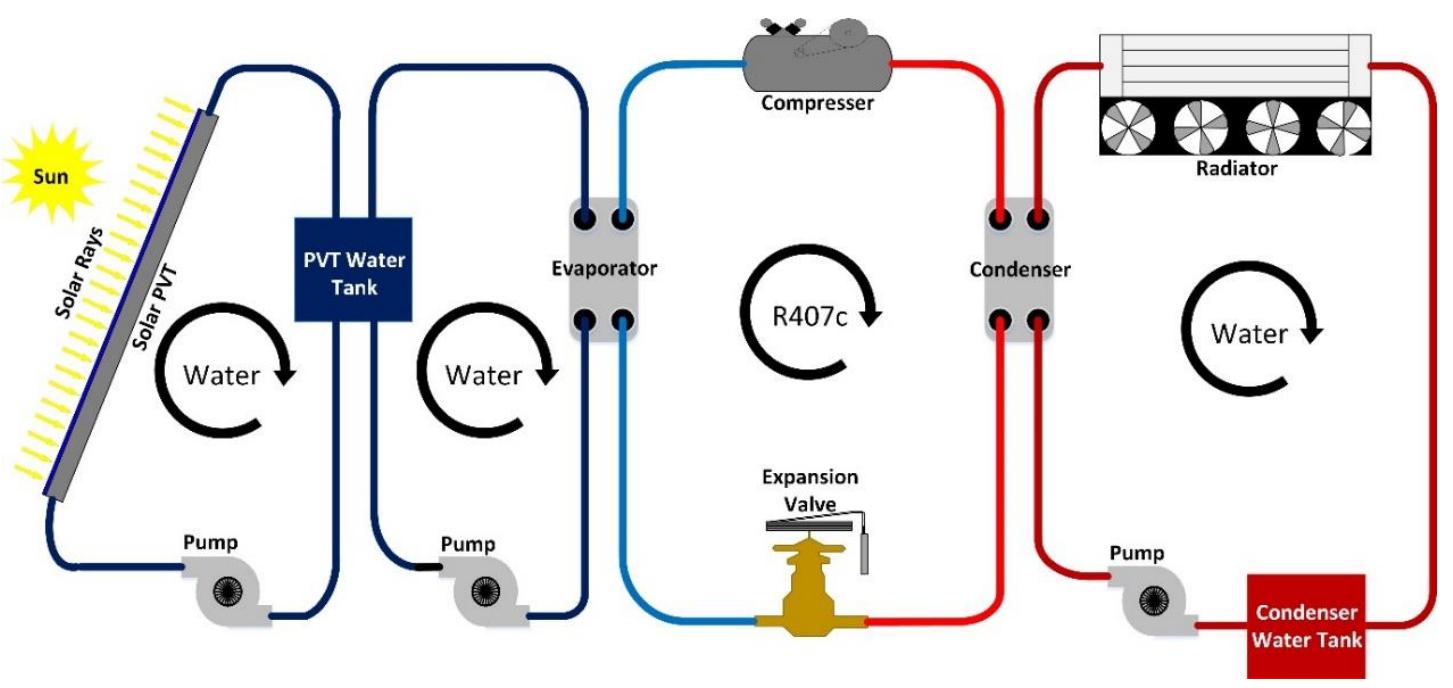

Figure 1: Layout of the PVT/HP system.

The operation of the system in Figure 1 is described as follows: the solar PVT absorbs sunlight and converts it to electricity and heat. The heat is absorbed by the cooling water, which is returned and stored in the PVT water tank. The heat pump refrigerant (i.e. R407c) absorbs heat stored in the water of the PVT water tank. The water exiting the evaporator is cycled back into the PVT water loop after it is cooled by the heat pump. The compressor increases the temperature of the refrigerant, which eventually releases the heat via the condenser to the heat rejection water loop. The heated water is pumped through a radiator from the condenser and is used to heat an indoor space before returning to the condenser water tank.

\section{Mathematical Modelling}

The mathematical model of the system is based on equations representing the thermodynamic and heat transfer processes occurring in the system. The model is a quasi-steady state model that takes incremental time steps to solve for the fluid temperature changes within the system. MATLAB code was developed to solve the system of governing equations. The Runge-Kutta $4^{\text {th }}$ order method was employed to solve the PVT energy balance equations. The heat pump equations were iterated to a solution within a specified tolerance of $10^{-6}$. The code was linked to CoolProp 6.1.1 [27] and REFPROP 9.0 [28] plug-ins to calculate the thermodynamic properties of the water and the refrigerant, respectively, for the heat pump. The PVT used mathematical relations proposed by Chow [29] and implemented by Yazdanifard et al [30] to calculate the thermodynamic properties of the water passing through the panel efficiently. The mathematical procedure used to solve the equations representing the system's operation is described in Appendix C. 


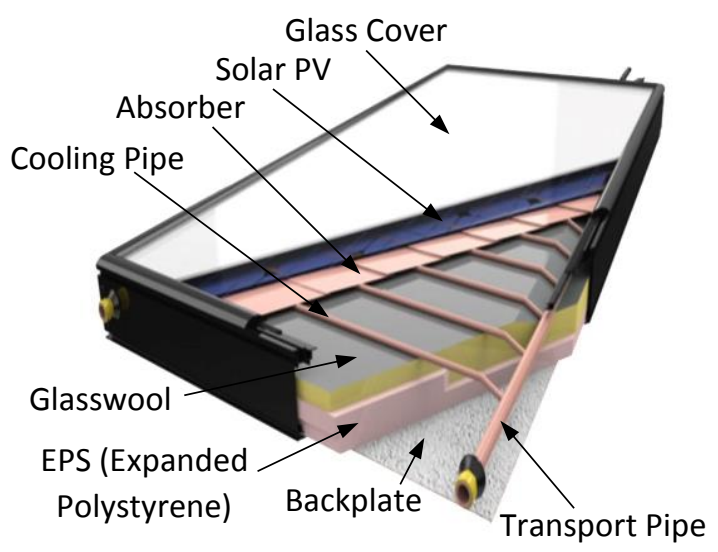

Figure 2(a): PVT piping layout [31].

\subsection{Photovoltaic-Thermal Panel}

The Photovoltaic-Thermal (PVT) panel modelled in this study is based on a commercially available PVT from Solimpeks Solar Energy Corp [31], shown in Figure 2.

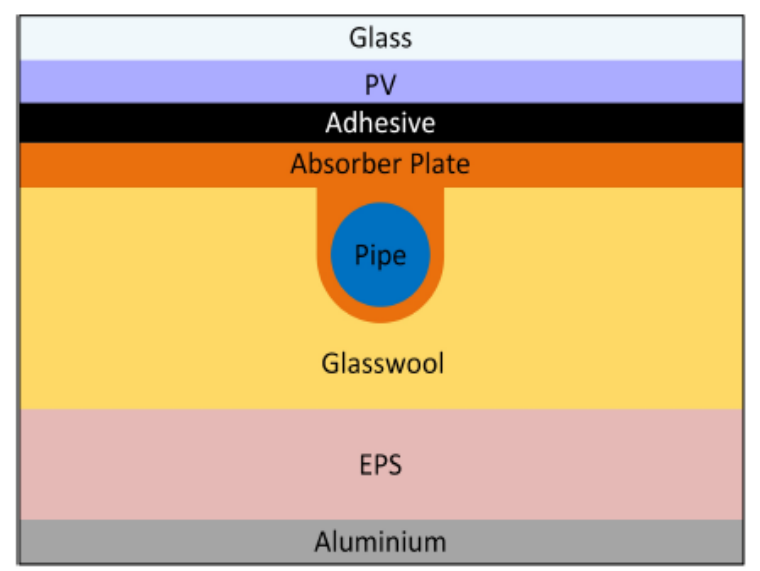

Figure 2(b): Internal PVT layering.
110

111
The PVT energy balance equations are given by Equations (1) - (10):

Glass Cover

$$
I \alpha_{g} w d x=\left(h_{c, g-a}+h_{r, g-s}\right)\left(T_{g}-T_{a}\right) w d x+(h d A)_{p v-g}\left(T_{g}-T_{p v}\right) .
$$

PV Panel

$$
\begin{gathered}
I \tau_{g} \alpha_{p v}\left[1-P A \eta_{r}\left(1-B_{r}\left(T_{p v}-T_{a}\right)\right)\right] w d x=(h d A)_{p v-g}\left(T_{p v}-T_{g}\right)+ \\
(h d A)_{p v-a b s}\left(T_{p v}-T_{a b s}\right) .
\end{gathered}
$$

Thermal Absorber

$$
(h d A)_{p v-a b s}\left(T_{p v}-T_{a b s}\right)=(h d A)_{a b s-t}\left(T_{a b s}-T_{t}\right)+(h d A)_{a b s-i g}\left(T_{a b s}-T_{i g}\right) .
$$

Pipe and Bonding

$$
(h d A)_{a b s-t}\left(T_{a b s}-T_{t}\right)=(h d A)_{t-w}\left(T_{t}-\bar{T}_{w}\right)+(h d A)_{t-i g}\left(T_{t}-T_{i g}\right) .
$$

\section{Insulation (Glasswool)}

$$
(h d A)_{a b s-i g}\left(T_{a b s}-T_{i g}\right)+(h d A)_{t-i g}\left(T_{t}-T_{i g}\right)=(h d A)_{i g-i p}\left(T_{i g}-T_{i p}\right) .
$$

Working Fluid in the Tube (pipes in the PVT)

$$
(h d A)_{t-w}\left(T_{t}-\bar{T}_{w}\right)=\dot{m} C_{p, w} d T_{w},
$$

where the average temperature of the water inside the pipe is:

$$
\bar{T}_{w}=\frac{1}{L} \int_{0}^{L} T_{w}(x) d x .
$$


Insulation (EPS)

$$
(h d A)_{i g-i p}\left(T_{i g}-T_{i p}\right)=(h d A)_{i p-a l}\left(T_{i p}-T_{a l}\right)
$$

123

Aluminium Back Plate

$$
(h d A)_{i p-a l}\left(T_{i p}-T_{a l}\right)=h_{c, a l-a}\left(T_{a l}-T_{a}\right) w d x .
$$

The coefficients of heat transfer, ( $h d A$ ), used in Equations (1) - (10) are given in Appendix A. By solving the above coupled equations, the temperatures of the cooling water at the inlet $\left(T_{i}\right)$ and outlet $\left(T_{o}\right)$ of the PVT are calculated. Hence, the thermal efficiency of the PVT is calculated as

$$
\eta_{\text {therm }}=\frac{\dot{m} C_{p_{w}}\left(T_{o}-T_{i}\right)}{I \cdot A} .
$$

The electrical efficiency, given in Equation (11), is based on the reference efficiency ( $\eta_{\text {ref }}$ ) of the solar cells in standard conditions (i.e. reference temperature $\left(T_{r e f}\right)$ of $25^{\circ} \mathrm{C}$ and light source intensity $(I)$ of $\left.1000 \mathrm{~W} / \mathrm{m}^{2}\right)$ :

$$
\eta_{\text {elec }}=\eta_{\text {ref }}\left[1-\beta\left(T_{P V}-T_{\text {ref }}\right)\right]
$$

The total efficiency of the PVT is the combined value of the electrical efficiency Equation (11) and thermal efficiency Equation (10), which is given by Equation (12):

$$
\eta_{\text {total }}=\eta_{\text {elec }}+\eta_{\text {therm }}
$$

\subsection{Heat Pump}

The heat pump, in Figure 1, uses the PVT water tank as an energy source, and the condenser water tank as an energy sink, which rejects heat to the user. The heat pump uses the refrigerant R407c, as the working fluid [32]. The performance of the heat pump is represented by the coefficient of performance (COP), which is the ratio of compressor work $\left(\dot{W}_{k}\right)$ to the heat output of the condenser $\left(\dot{Q}_{c}\right)[33]$ :

$$
C O P_{H P}=\frac{\dot{Q}_{c}}{\dot{W}_{k}}
$$

Since a hybrid PVT heat pump system generates both heat and electrical energy, a combined coefficient of thermal-and-electrical performance $\left(C O P_{P V T / H P}\right)$ is used in this study [14] given by Equation (14). In this equation, $\dot{E}_{\text {elec }}$ is the net electricity production from the PV [14]:

$$
\operatorname{COP}_{P V T / H P}=\frac{\dot{Q}_{c}+\dot{E}_{\text {elec }}}{\dot{W}_{k}}=\underbrace{\frac{\dot{Q}_{c}}{\dot{W}_{k}}}_{C O P_{H P}}+\frac{\dot{E}_{\text {elec }}}{\dot{W}_{k}} .
$$

144 The heat pump components are divided into the compressor, condenser, evaporator and expansion valve, with details of the equations given in Appendix B. 
147 To study how the temperature variations of the water tanks influence the performance of the system, the model is time stepped to give discrete results over a time period. The change of

$$
T_{\text {tank,new }}=T_{\text {tank,old }}+\frac{\left(\dot{Q}_{\text {in }}-\dot{Q}_{\text {out }}\right)}{m_{w, \text { tank }} C_{p, w}} d t .
$$

\section{Validation}

In this study, the two main parts of the system (i.e. the PVT and the heat pump) are validated against numerical and experimental data recorded in the literature.

\subsection{PVT Panel}

The results of the PVT model calculated using the present model are shown in Figure 3 and compared against the experimental data of Huang et al. [35]. Figure 3 illustrates the PV temperature and the temperature of the cooling water exiting the PVT as a function of time. The figure shows that the results predicted by the present model are in good agreement with the experimental data of Huang et al. [35].

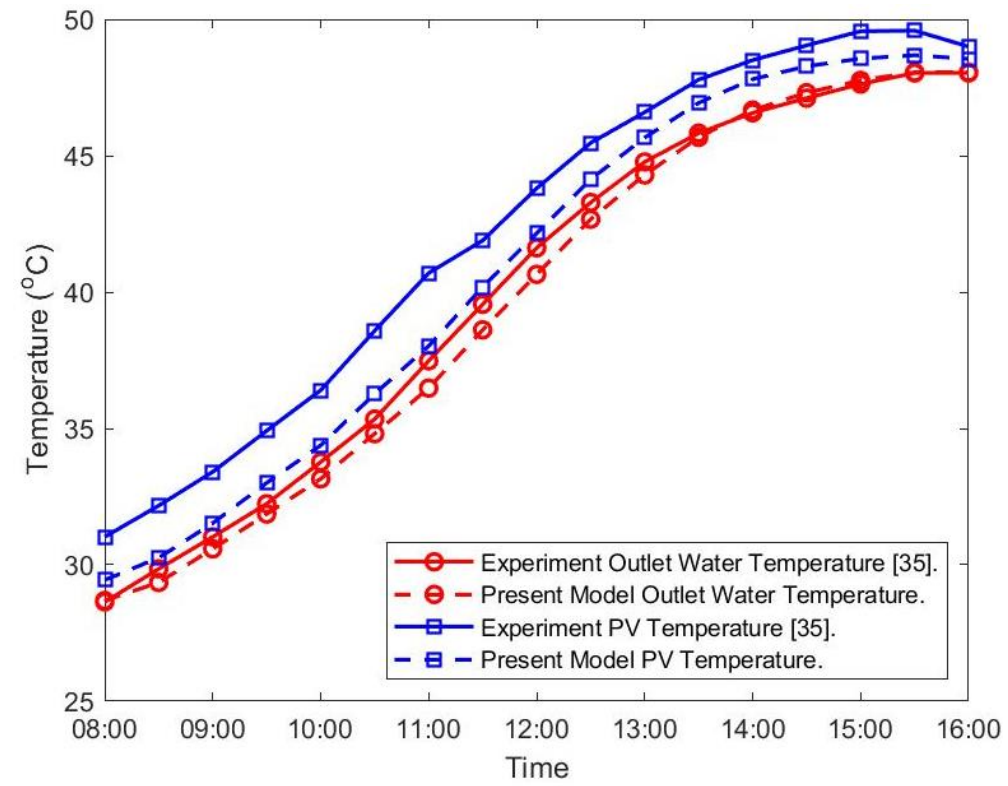

Figure 3: PV temperature and PVT water outlet temperature calculated using the present model against the experimental data of Huang et al. [35].

\subsection{Heat Pump}

The results predicted by the present heat pump model are compared to the numerical data of Camdali et al. [36] for a ground source heat pump as well as experimental data of AbuMulaweh [37] for an air source heat pump. The coefficient of performance, compressor work and temperature at different locations (i.e. 1: evaporator outlet, 2: compressor outlet, 3: condenser outlet, 4: expansion valve outlet) predicted by the present model are compared against those reported in refs. [36] and [37], shown in Table 1. The present results are in good agreement with the previous experimental and numerical data. 
Table 1: Validation of Heat Pump Model.

\begin{tabular}{lcccc}
\hline Variable & $\begin{array}{c}\text { Camdali } \\
\text { et al. [36] }\end{array}$ & $\begin{array}{c}\text { Present } \\
\text { Model }\end{array}$ & $\begin{array}{c}\text { Abu-Mulaweh } \\
\text { [37] }\end{array}$ & $\begin{array}{c}\text { Present } \\
\text { Model }\end{array}$ \\
\hline $\begin{array}{l}\text { Compressor } \\
\text { Power }(\mathrm{W})\end{array}$ & 426.16 & 429.17 & 51.6 & 52.9 \\
\hline $\begin{array}{l}\text { Coefficient of } \\
\text { Performance }\end{array}$ & 3.31 & 3.27 & 3.5 & 3.7 \\
\hline$T_{1}\left({ }^{\circ} \mathrm{C}\right)$ & -6.6 & -6.7 & 10.5 & 11.2 \\
$T_{2}\left({ }^{\circ} \mathrm{C}\right)$ & 49.6 & 49.5 & 78.7 & 80.5 \\
$T_{3}\left({ }^{\circ} \mathrm{C}\right)$ & 33.2 & 33.1 & 17.9 & 18.9 \\
$T_{4}\left({ }^{\circ} \mathrm{C}\right)$ & -6.6 & -6.7 & -8.05 & -8.1 \\
\hline
\end{tabular}

\section{Results and Discussion}

171 The system modelled in Figure 1 is used to simulate the heating of a $5 \mathrm{~m} \times 3 \mathrm{~m} \times 3 \mathrm{~m}$ space using a radiator of dimension $2 \mathrm{~m} \times 0.15 \mathrm{~m} \times 0.15 \mathrm{~m}$. The radiator uses forced convection with an air velocity of $0.5 \mathrm{~m} / \mathrm{s}$. The room starts at an ambient temperature of $14^{\circ} \mathrm{C}$ (i.e. the average summer temperature in Belfast, UK [38]) and the system operates for 3600 seconds. The initial water temperatures in the condenser water tank and PVT water tank are considered to be the same as ambient air temperature. The condenser water mass flow rate is $0.075 \mathrm{~kg} / \mathrm{s}$. The PVT panel has 14 copper pipes allowing cooling water to flow through the back of the PVT. The pipes have an $8 \mathrm{~mm}$ external diameter with $1.2 \mathrm{~mm}$ wall thickness. The flow changes from laminar to turbulent in the pipe at a Reynolds number of 2300 [30]. The change from laminar to turbulent flow affects the Nusselt number in the PVT panel, and is determined by Equations (A-8) and (A-9). The effects of different parameters including solar irradiation $(I)$, volumetric flow rate of the PVT cooling water $(\dot{V}=\dot{m} / \rho)$ and the size of the water tank $(V)$ on the system performance are analysed. Other parameters used in the model are described in Table 2.

Table 2: Parameters used in the model.

\begin{tabular}{llll}
\hline Components & Parameter & Value & Units \\
\hline Glass Cover & Thickness & 0.0032 & $\mathrm{~m}$ \\
& Transmittance & 0.9 & \\
& Absorption coefficient & 0.1 & \\
& Material & Low-iron tempered glass & \\
\hline PV Panel & Thickness & 0.00022 & $\mathrm{~m}$ \\
& Thermal conductivity & 140 & $\mathrm{~W} / \mathrm{mK}$ \\
& Emissivity & 0.9 & \\
& Reference efficiency & 0.1508 & \\
& Temperature correction factor & 0.0045 & \\
& Absorption coefficient & 0.9 & $\mathrm{~m}$ \\
& PV surface length & 0.75 & $\mathrm{~m}$ \\
& PV surface width & 1.5 & $\mathrm{~K}$ \\
& Reference temperature & 298.15 & $\mathrm{~m}$ \\
& Material & Mono-crystalline Silicon & $\mathrm{W} / \mathrm{mK}$ \\
& Thickness & 0.0004 & $\mathrm{~m}$ \\
& Thermal conductivity & 0.2 & $\mathrm{~m}$ \\
& Material & Ethylene-vinyl acetate (EVA) & $\mathrm{m}$ \\
& Thickness & 0.0012 & $\mathrm{~W} / \mathrm{mK}$
\end{tabular}




\begin{tabular}{|c|c|c|c|}
\hline & $\begin{array}{l}\text { Packing factor } \\
\text { Material }\end{array}$ & $\begin{array}{l}0.996 \\
\text { Copper }\end{array}$ & \\
\hline \multirow[t]{3}{*}{ Glasswool Insulation } & Thickness & 0.05 & \\
\hline & Thermal conductivity & 0.04 & $\mathrm{~W} / \mathrm{mK}$ \\
\hline & Material & Fibreglass & \\
\hline \multirow[t]{3}{*}{ EPS Insulation } & Thickness & 0.04 & \\
\hline & Thermal conductivity & 0.04 & $\mathrm{~W} / \mathrm{mK}$ \\
\hline & Material & Expanded polystyrene & \\
\hline \multirow[t]{3}{*}{ Backplate } & Thickness & 0.0025 & \\
\hline & Thermal conductivity & 206 & $\mathrm{~W} / \mathrm{mK}$ \\
\hline & Material & Aluminium & \\
\hline \multirow[t]{3}{*}{ Working Fluid } & Initial temperature & 287.15 & K \\
\hline & Thermal conductivity & 0.04 & $\mathrm{~W} / \mathrm{mK}$ \\
\hline & Material & Water & \\
\hline \multirow[t]{5}{*}{ Cooling Pipes } & Number & 14 & \\
\hline & Thermal conductivity & 400 & $\mathrm{~W} / \mathrm{mK}$ \\
\hline & Outer diameter & 0.008 & \\
\hline & Inner diameter & 0.0056 & $\mathrm{~m}$ \\
\hline & Material & Copper & \\
\hline \multirow[t]{2}{*}{ Module } & PV surface length & 0.828 & $\mathrm{~m}$ \\
\hline & PV surface width & 1.655 & $\mathrm{~m}$ \\
\hline \multirow[t]{3}{*}{ Transport Pipe } & Inner diameter & 0.0196 & $\mathrm{~m}$ \\
\hline & Outer diameter & 0.022 & $\mathrm{~m}$ \\
\hline & Material & Copper & \\
\hline \multirow[t]{2}{*}{ Condenser } & Mass flow rate & 0.2 & $\mathrm{~kg} / \mathrm{s}$ \\
\hline & Area & 0.61875 & $\mathrm{~m}^{2}$ \\
\hline \multirow[t]{3}{*}{ Compressor } & Isentropic efficiency & 0.7 & \\
\hline & Displacement volume & $12.045 \times 10^{-5}$ & $\mathrm{~m}^{3}$ \\
\hline & Compressor efficiency & 0.91 & \\
\hline \multirow[t]{2}{*}{ Evaporator } & Mass flow rate & 0.1 & $\mathrm{~kg} / \mathrm{s}$ \\
\hline & Area & 0.61875 & $\mathrm{~m}^{2}$ \\
\hline
\end{tabular}

\subsection{Solar Irradiation}

This section presents the results of the system's operation for different solar irradiation in the range of $I=\left[250 \mathrm{~W} / \mathrm{m}^{2}-1000 \mathrm{~W} / \mathrm{m}^{2}\right]$. The PVT cooling water from the PVT water tank has a fixed flow rate of $\dot{V}=5 \mathrm{~L} / \mathrm{min}$ and the size of the PVT water tank used in this section is $V=50 \mathrm{~L}$.

\subsubsection{Temperature Variation with Solar Irradiation}

190 Figure 4 represents the variation in PVT panel temperature over the operational time of the system for different solar irradiation intensities. For a fixed time, as the solar irradiation intensity increases the PVT temperature increases, as discussed in previous research (e.g. [30]). An increase in the solar irradiation leads to an increase in the amount of solar energy converted to heat. The increased heat causes a rise in the PVT temperature. Figure 4 also shows that the change in PVT temperature with time is not uniform across the irradiation intensities. For the intensity of $750 \mathrm{~W} / \mathrm{m}^{2}$, the PVT temperature remains almost constant at approximately $24^{\circ} \mathrm{C}$ during the operation of the system. When the solar irradiation is increased to $1000 \mathrm{~W} / \mathrm{m}^{2}$, the PVT temperature increases with time. However, for lower intensities of $500 \mathrm{~W} / \mathrm{m}^{2}$ and $250 \mathrm{~W} / \mathrm{m}^{2}$, the PVT temperature decreases over time. The PVT is modelled using energy balance equations, the only factor that changes over time and influences the rest of the PVT 
does not change over time for each analysis, the differences observed in Figure 4 is best described by the influence of the temperature of the cooling water that flows through the PVT and stored in the PVT water tank (Figure 5).

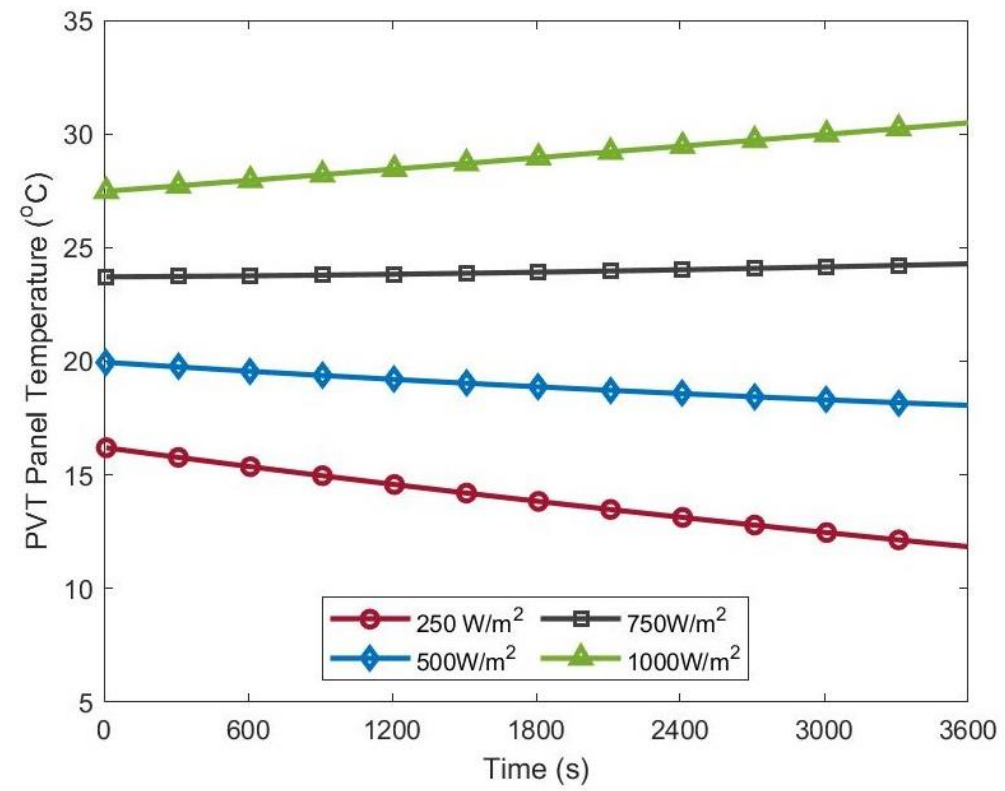

Figure 4: Temperature of the PV over time for different solar irradiances with $\dot{V}=5 \mathrm{~L} / \mathrm{min}$ and $V=50 \mathrm{~L}$.

Figure 5 illustrates the variation of the PVT water tank temperature over time for different solar irradiation intensities. With the exception of the initial temperature of the PVT water tank, which was set at $14^{\circ} \mathrm{C}$, at any fixed time, an increase in solar irradiation gives an increase in the PVT water tank temperature. High solar irradiation means an increase in the heat absorbed by the PVT, which makes more heat available to be absorbed by the water passing through the PVT pipes. The cooling water transports this heat to the PVT water tank, and thus the water tank temperature increases.

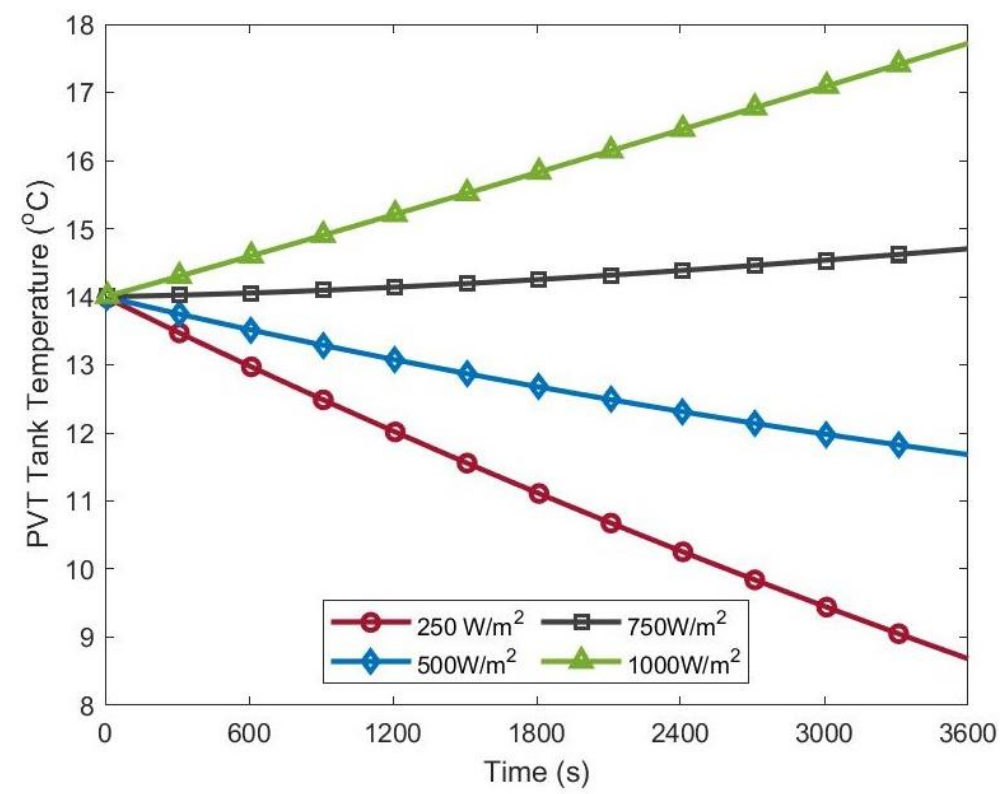

Figure 5: Variation in PVT water tank temperature over time for different PVT irradiances with $\dot{V}=5 \mathrm{~L} / \mathrm{min}$ and $V=50 \mathrm{~L}$. 
The temperature of the PV panel in Figure 4 and the temperature of the PVT water tank in

212 Figure 5, for the configuration analysed, are invariably linked. These observations demonstrate 213 that the PVT panel temperature is highly influenced by the water temperature in the water tank, 214 and that the water temperature in the water tank is highly influenced by the PV panel. Hence, 215 controlling the PVT water tank is key to controlling the temperature of the PV panel.

\section{$216 \quad$ 5.1.2 Efficiency Variation with Solar Irradiation}

217 Figure 6 shows the variation in electrical efficiency of the PVT panel over the operational time 218 of the system for different solar irradiation intensities. For a fixed time, an increase in solar 219 irradiation results in a decrease in electrical efficiency. The electrical efficiency of the PVT panel is governed by Equation (11). This equation shows that the electrical efficiency of the PVT panel depends on three factors: reference electrical efficiency (i.e. $\eta_{\text {ref }}=0.1508$ ) [31], temperature correction coefficient (i.e. $\beta=0.0045$ ) [31] and temperature difference between the reference temperature $\left(T_{r e f}=25^{\circ} \mathrm{C}\right)$ and the PVT panel temperature $\left(T_{P V}\right)$, hence, the solar irradiation has no direct effect on the electrical efficiency of the PVT panel. Since $\eta_{\text {ref }}$ and $\beta$ both have fixed values in this study, the influence must come from the temperature difference between the reference temperature $\left(T_{r e f}\right)$ and PVT panel temperature $\left(T_{P V}\right)$. Figure 4 shows the PVT panel temperature increases as the solar irradiation increases, the inverse of the trend seen in Figure 6. Thus, the change in the PVT panel temperature is the cause for the variation of the electrical efficiency seen in Figure 6. This figure further shows that for solar irradiation of $750 \mathrm{~W} / \mathrm{m}^{2}$ very little change in electrical efficiency is seen over time. For $1000 \mathrm{~W} / \mathrm{m}^{2}$ solar irradiance, the electrical efficiency decreases over time, while for lower irradiations of $500 \mathrm{~W} / \mathrm{m}^{2}$ and $250 \mathrm{~W} / \mathrm{m}^{2}$, the electrical efficiency increases with time. The trend of the electrical efficiency over time follows an inverse trend to that of Figure 4, thus showing that increasing PVT temperature leads to decreasing the electrical efficiency.

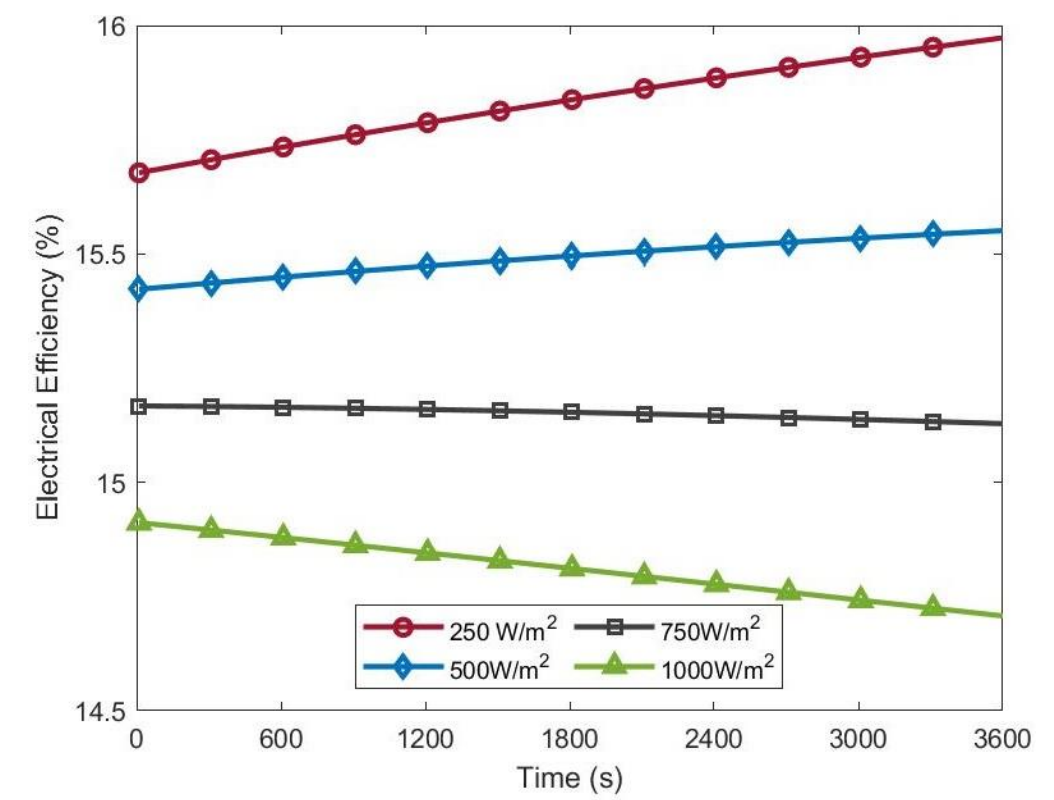

Figure 6: Electrical efficiency of the PVT over time for different solar irradiations with $\dot{V}=5 \mathrm{~L} / \mathrm{min}$ and $V=50 \mathrm{~L}$.

Figure 7 represents the variation of the PVT panel's thermal efficiency over the operational time of the system for different solar irradiation intensities. For the initial time interval, an increase in solar irradiation leads to an asymptotic increase in the thermal efficiency. The 
thermal efficiency of the PVT panel is dictated by Equation (10). In this analysis the volumetric flow rate $(\dot{m})$ and PVT panel area $(A)$ were kept constant and the change in $C_{P w}$ is negligible. Thus, the influential changing variables are the solar irradiance intensity $(I)$ and the temperature difference between the water exiting the PVT $\left(T_{o}\right)$ and the water entering the PVT $\left(T_{i}\right)$. Since $T_{i}$ is fixed for all solar irradiances $\left(T_{i}=14^{\circ} \mathrm{C}\right)$, therefore, the exiting water temperature $\left(T_{o}\right)$ is changing as the solar irradiation $(I)$ changes. As solar irradiation increases, the value of the denominator in Equation (10) increases. At the same time, an increase in the solar irradiation increases the water temperature exiting the PVT $\left(T_{o}\right)$, hence increases the difference between the water inlet and outlet temperatures in the numerator of Equation (10). However, the numerator of Equation (10) is increasing at a greater rate than the denominator, leading to an asymptotic increase in thermal efficiency.

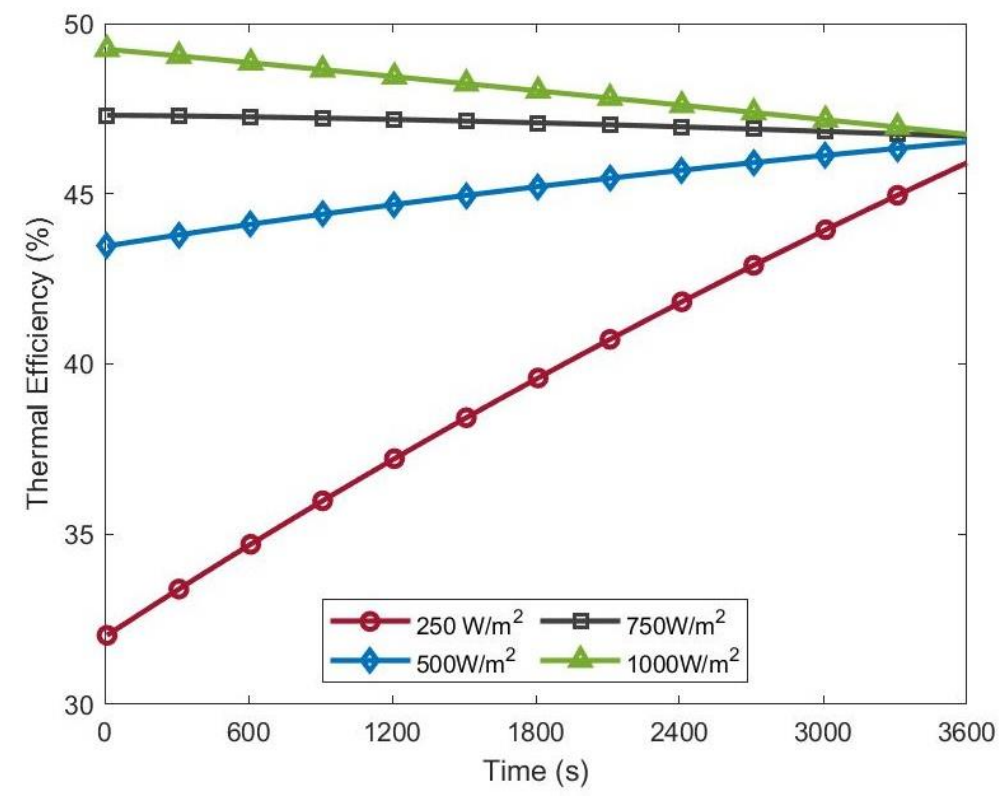

Figure 7: Thermal efficiency of the PVT over time for different irradiation intensities with $\dot{V}=5 \mathrm{~L} / \mathrm{min}$ and $V=50 \mathrm{~L}$.

249 Figure 8 shows the variation of the total efficiency of the PVT panel over time for different 250 solar irradiation intensities. The total efficiency is a ratio of the amount of solar irradiation converted into heat and electricity by the PVT compared to the total amount of solar irradiation exposed to the PVT panel (Equation (12)). The trend seen in Figure 8 is mainly influenced by the thermal efficiency. This is expected as the range in thermal efficiency is between $30 \%$ and $50 \%$ (Figure 7), while the range of the electrical efficiencies change is $14 \%$ to $16 \%$ (Figure 6). 


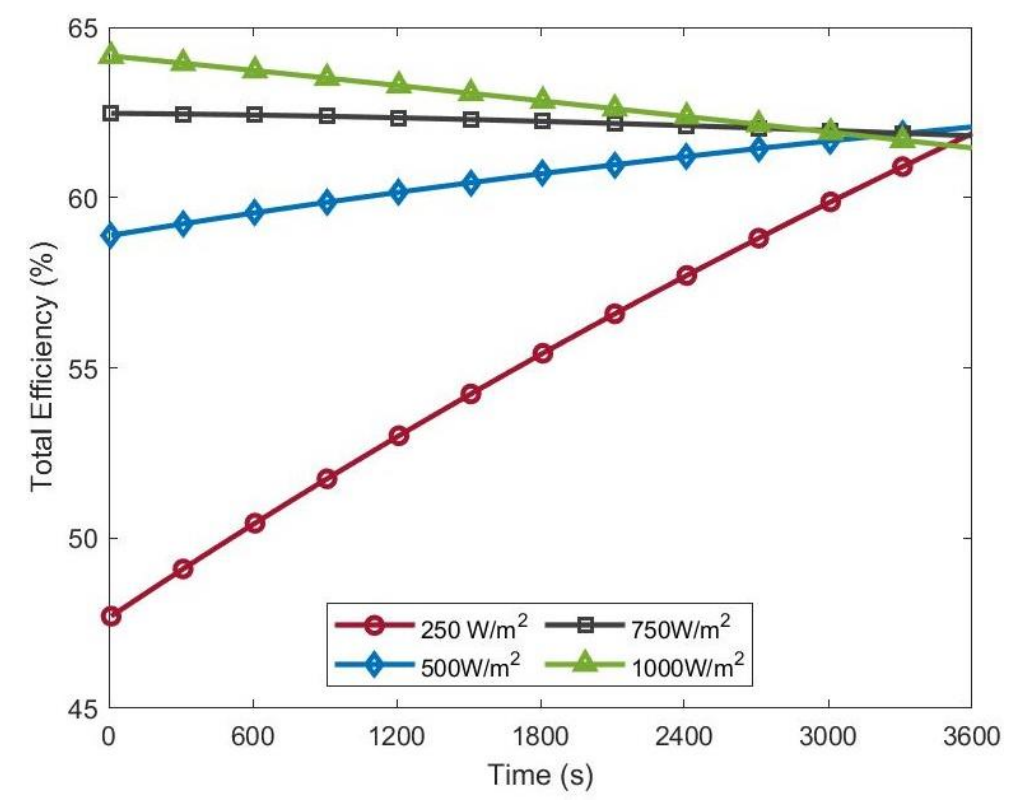

Figure 8: Total efficiency of the PVT module over time for different irradiation intensities with $\dot{V}=5 \mathrm{~L} / \mathrm{min}$ and $V=50 \mathrm{~L}$.

\subsubsection{Coefficient of Performance (COP) Variation with Solar Irradiation}

256 The coefficient of performance (COP) of the heat pump is represented in Figure 9. The figure shows that for a fixed solar irradiation, the COP decreases over time, which has also been reported in previous research (e.g. [39]). The reason for this behaviour is explained as follows. The COP is calculated using Equation (13), which is the heat rejected by the heat pump to the user $\left(\dot{Q}_{c}\right)$ divided by the compressor work $\left(\dot{W}_{k}\right)$. In the present modelling, the heat pump's compressor is considered to have a fixed speed, meaning that the compressor work $\left(\dot{W}_{k}\right)$ is constant during the operation of the heat pump. The equation governing the heat given by the heat pump to the user water loop through the condenser (Figure 1) are described by Equations (B-8) - (B-23). Actually, the value of $\dot{Q}_{c}$ is dictated by the temperature difference between the water and refrigerant in the condenser. As the heat pump works, the temperature in the user area increases, meaning that the temperature of the water in the condenser is close to the refrigerant temperature in the condenser. This will in turn, reduces the temperature difference across the condenser, hence reduces the rate of heat transfer $\left(\dot{Q}_{c}\right)$. Therefore, for a fixed $\left(\dot{W}_{k}\right)$ a reduction in $\left(\dot{Q}_{c}\right)$ leads to a decrease in the COP over time. 


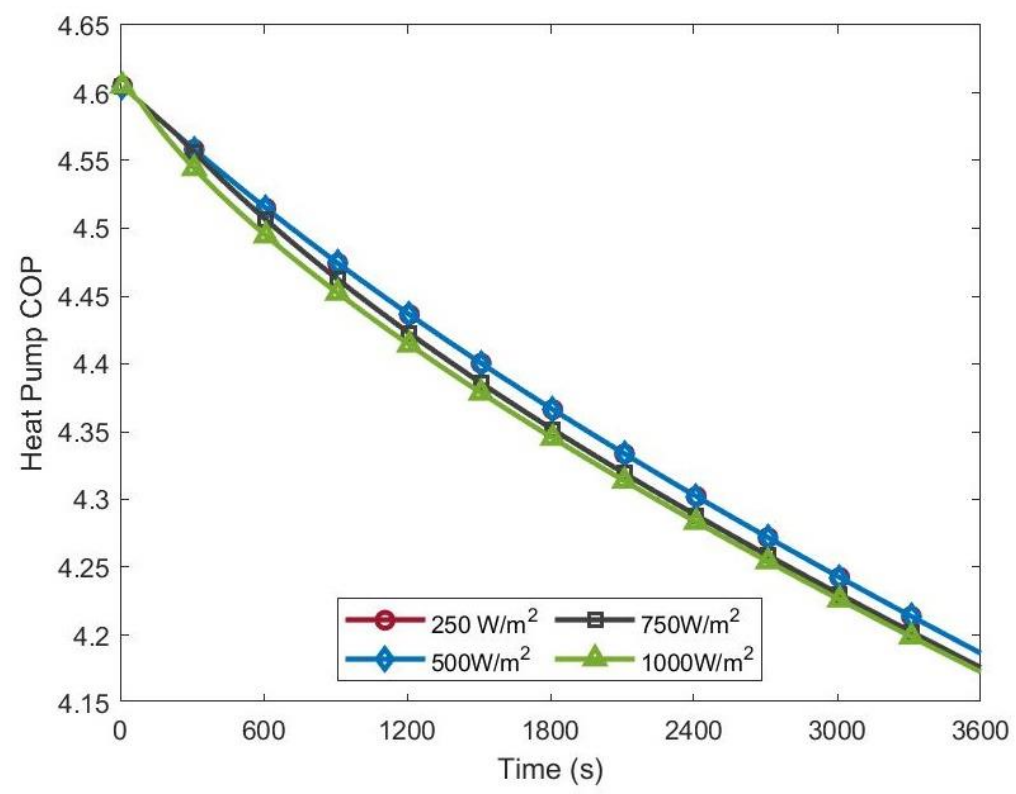

Figure 9: COP of a heat pump over time for different solar irradiances with $\dot{V}=5 \mathrm{~L} / \mathrm{min}$ and $V=50 \mathrm{~L}$.

270 Figure 9 further shows that the solar irradiation intensity has a negligible effect on the variation 271 of the heat pump COP. The heat pump uses the PVT water tank as its heat source. However, the 272 heat pump is modelled as fixed speed, which means the change in heat transfer through the 273 condenser is negligible with changing solar irradiation. The solar irradiation intensity affects the 274 temperature of the PVT tank. In the simulations, the tank temperatures have a maximum 275 difference in temperature of $9^{\circ} \mathrm{C}$ at 3600 seconds as shown in Figure 5. This difference in 276 temperature does not result in a significant change in the heat transferred from the tank to the 277 heat pump meaning there is no significant change in the amount of heat given by the condenser. 278 Hence, the COP of the heat pump does not vary significantly with the change in solar irradiation.

279 The COP of the combined IEPVT/HP system (Equation (14)) is shown in Figure 11 for different 280 solar irradiance over time. It is seen that with increasing the solar irradiation intensity, the combined 281 COP increases. According to Equation (14), both the COP of the heat pump and the output 282 electricity of the PVT contribute to the combined COP as $C O P_{P V T / H P}=C O P_{H P}+\dot{E}_{\text {elec }} / \dot{W}_{k}$. From 283 Figure 9 it is seen that the solar irradiation has a negligible effect on the heat pump COP. Since the 284 compressor work $\left(\dot{W}_{k}\right)$ is constant in this modelling, the main cause of increasing the combined 285 COP with the solar intensity is due to increasing the electrical energy production $\dot{E}_{\text {elec }}$ ( $40 \mathrm{~W}$ at $286250 \mathrm{~W} / \mathrm{m}^{2}$ and $147 \mathrm{~W}$ at $1000 \mathrm{~W} / \mathrm{m}^{2}$ ). By increasing the solar irradiation more solar energy is 287 converted to electricity, thus the increased electricity production leads to a higher $C O P_{P V T / H P}$. 


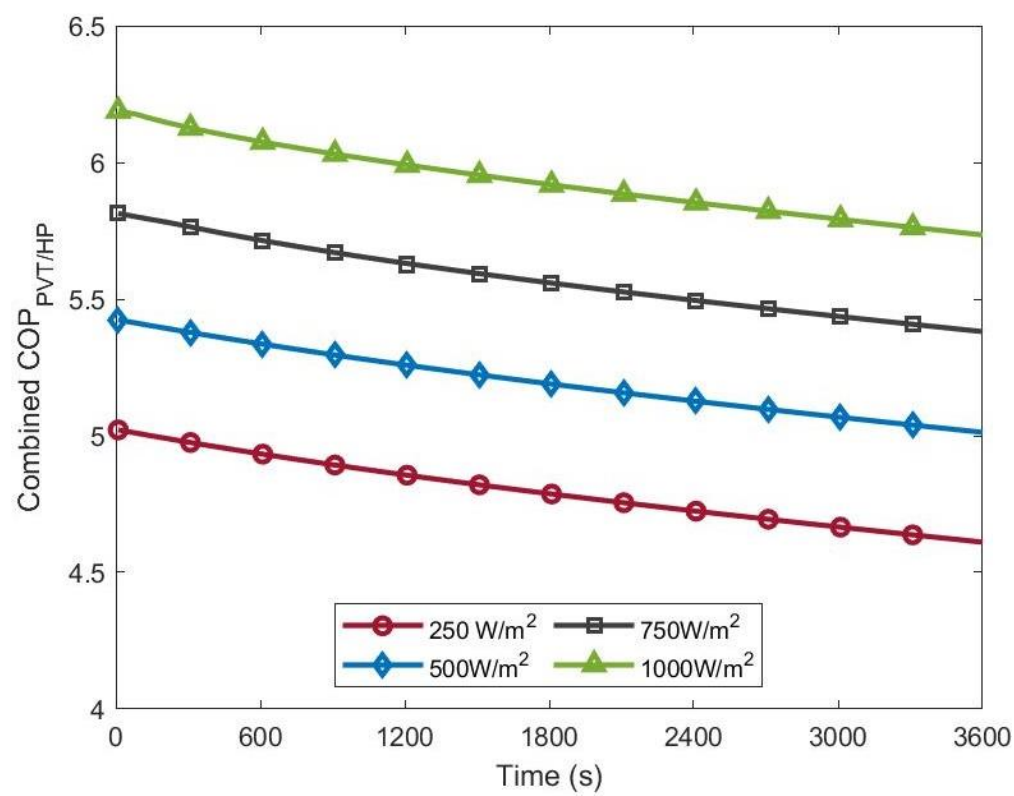

Figure 10: Combined COP of the PVT module and heat pump $\left(\operatorname{COP}_{P V T / H P}\right)$ over time for different solar irradiances with $\dot{V}=5 \mathrm{~L} / \mathrm{min}$ and $V=50 \mathrm{~L}$.

\subsection{Water flow rate in the PVT}

In this section, the effect of variation in water flow rate through the PVT pumping cycle on the system performance is analysed. The volumetric flow rate of the water considered is within the range of $\dot{V}=[3 \mathrm{~L} / \mathrm{min}-17 \mathrm{~L} / \mathrm{min}]$ with a corresponding Reynolds number based on the hydraulic diameter of the PVT water pipe is $R e \approx[700-4000]$ and a solar irradiation intensity of $I=750 \mathrm{~W} / \mathrm{m}^{2}$. The solid lines represent laminar flow regimes $(R e<2300)$ in the PVT pipe, while the dashed lines represent turbulent flow regimes.

\subsubsection{Temperature Variation with Water Flow Rate}

Figure 11 shows the variation in the PVT temperature over time for different volumetric flow rates. The figure shows that for the laminar flow rates $(3 \mathrm{~L} / \mathrm{min}-9 \mathrm{~L} / \mathrm{min})$ and the turbulent flow rates $(11 \mathrm{~L} / \mathrm{min}-17 \mathrm{~L} / \mathrm{min})$, there is an asymptotic decrease in the temperature of the PVT panel as the water flow rate increases. It is seen that increasing the water flowrate from $3 \mathrm{~L} / \mathrm{min}$ to $17 \mathrm{~L} / \mathrm{min}$ decreases the PVT panel temperature from $25^{\circ} \mathrm{C}$ to $21.5^{\circ} \mathrm{C}$. For the turbulent flow cases $(11 \mathrm{~L} / \mathrm{min}-17 \mathrm{~L} / \mathrm{min})$, the PVT temperature drops significantly compare to the laminar flow case trend. This is attributed to a higher heat transfer rate from the PVT to the cooling water in the turbulent flow regime than the laminar flow regime. The jump indicates that there is a discontinuity of cooling effect between laminar and turbulent flow through the PVT panel, an effect that has previously been observed by Yazdanifard et al. [30]. 


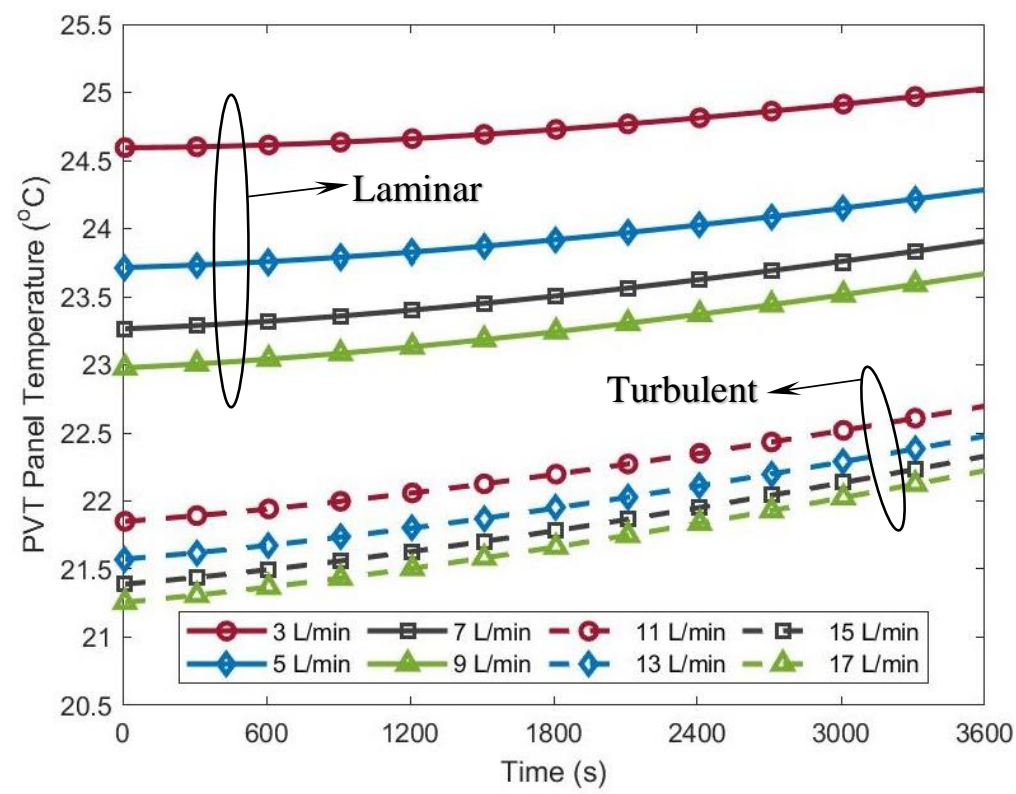

Figure 11: Temperature of the PVT over time for different PVT water flow rates with $I=750 \mathrm{~W} / \mathrm{m}^{2}$ and $V=50 \mathrm{~L}$.

\subsubsection{Efficiency Variation with Water Flow Rate}

Figure 12 represents the change in electrical efficiency of the PVT panel for different volumetric flow rates over time. As the water flow rate increases from $3 \mathrm{~L} / \mathrm{min}$ to $17 \mathrm{~L} / \mathrm{min}$, the electrical efficiency of the PVT panel increases by about $0.25 \%$. From Equation (11), it has been established that electrical efficiency is closely connected to the PVT panel temperature. Figure 11 showed that by decreasing the water flow rate, the PVT panel temperature increases, which leads to a decrease in the electrical efficiency of the panel. Such an effect of cooling on increasing the PVT efficiency has also been observed in previous research [13].

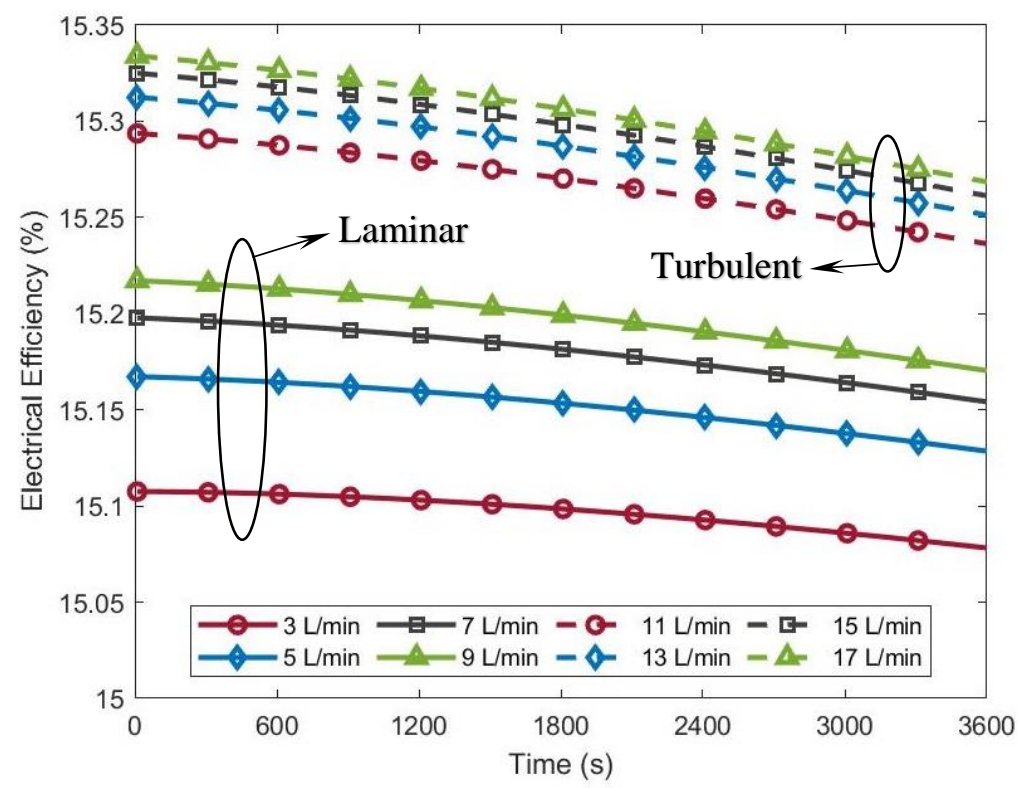

Figure 12: Electrical efficiency of the PVT over time for different PVT water flow rates with $I=750 \mathrm{~W} / \mathrm{m}^{2}$ and $V=50 \mathrm{~L}$.

Figures 13 and 14 show the change in the PVT thermal and total efficiency, respectively, over time 
from $3 \mathrm{~L} / \mathrm{min}$ to $17 \mathrm{~L} / \mathrm{min}$ increases the thermal and total efficiency by about $3.6 \%$ and $3.8 \%$, respectively.

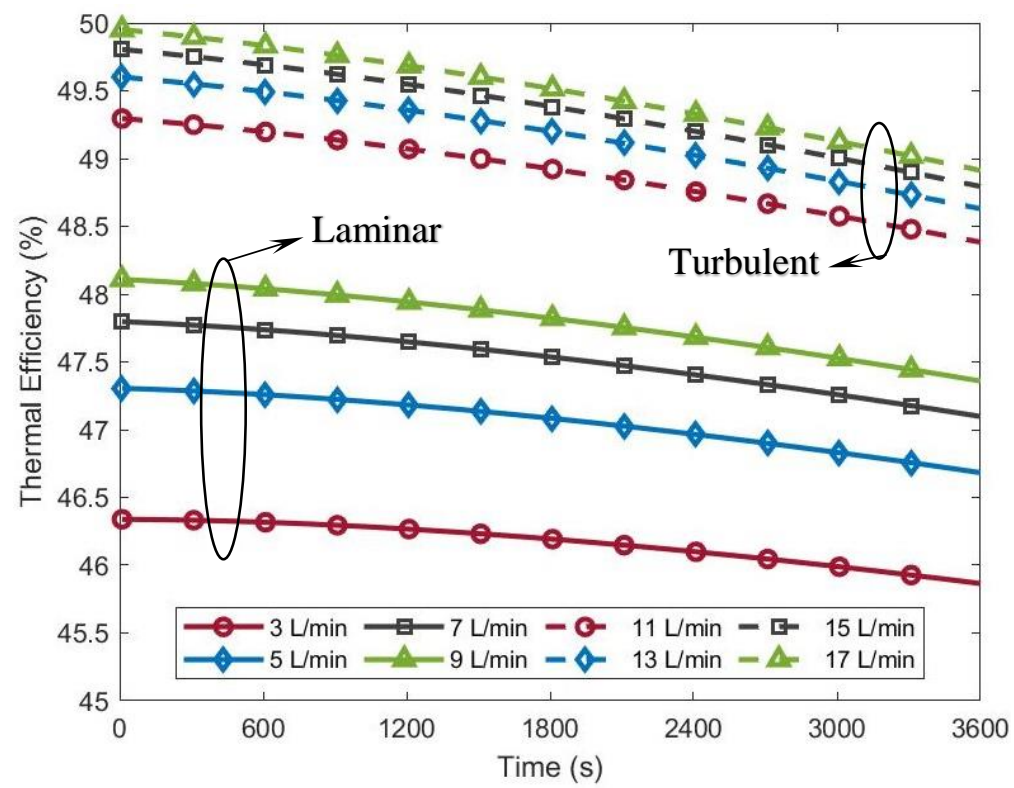

Figure 13: Thermal efficiency of the PVT over time for different PVT water flow rates with $I=750 \mathrm{~W} / \mathrm{m}^{2}$ and $V=50 \mathrm{~L}$.

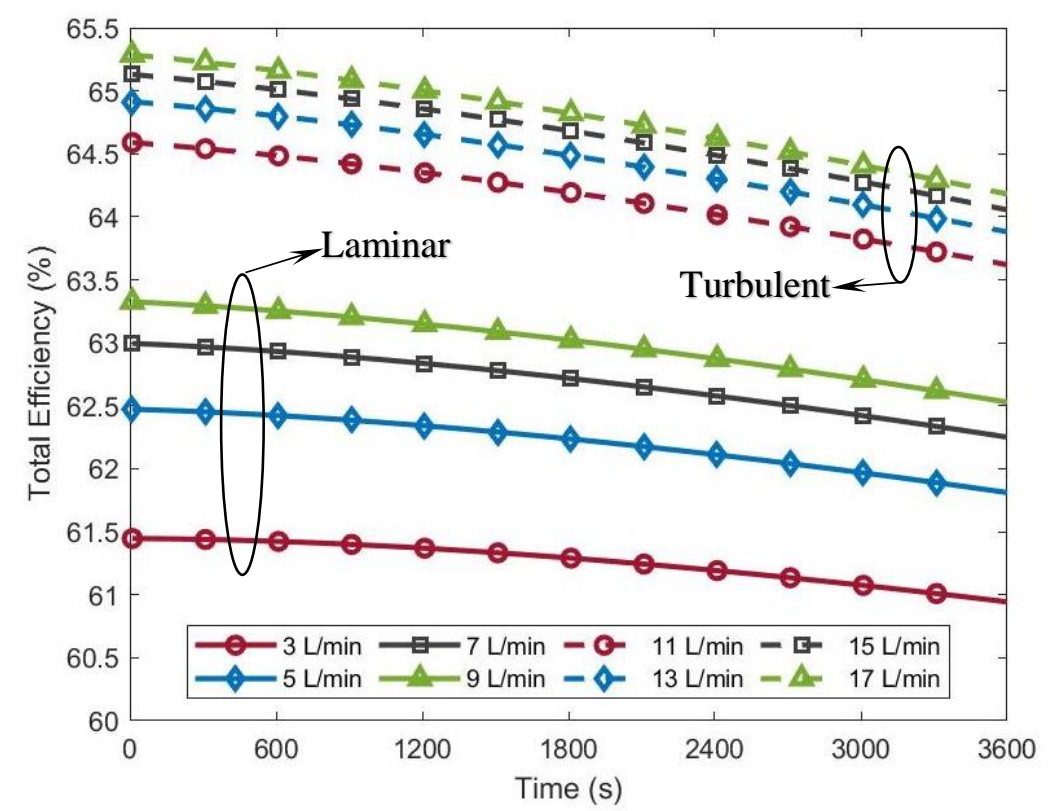

Figure 14: Total efficiency of the PVT module over time for different PVT water flow rates with $I=750 \mathrm{~W} / \mathrm{m}^{2}$ and $V=50 \mathrm{~L}$.

\subsubsection{Coefficient of Performance (COP) Variation with Water Flow Rate}

319 Figure 15 represents the change in coefficient of performance (COP) of the heat pump for 320 different volumetric flow rates over time. The COP of the heat pump shows a negligible variation with change of the PVT water flow rate. This is due to the same mechanism that causes negligible variation in heat pump COP in Figure 9. The two variables for the COP of the heat pump are the compressor work $\left(\dot{W}_{k}\right)$ and the condenser heat output $\left(\dot{Q}_{c}\right)$. The compressor work is fixed in the present modelling. A change in the PVT water flow rate 
influences the temperature of the heat pump's heat source (i.e. PVT water tank). However, as discussed in Section 5.1.3, the change in the heat source's temperature has negligible influence on the performance of the heat pump with a fixed compressor work.

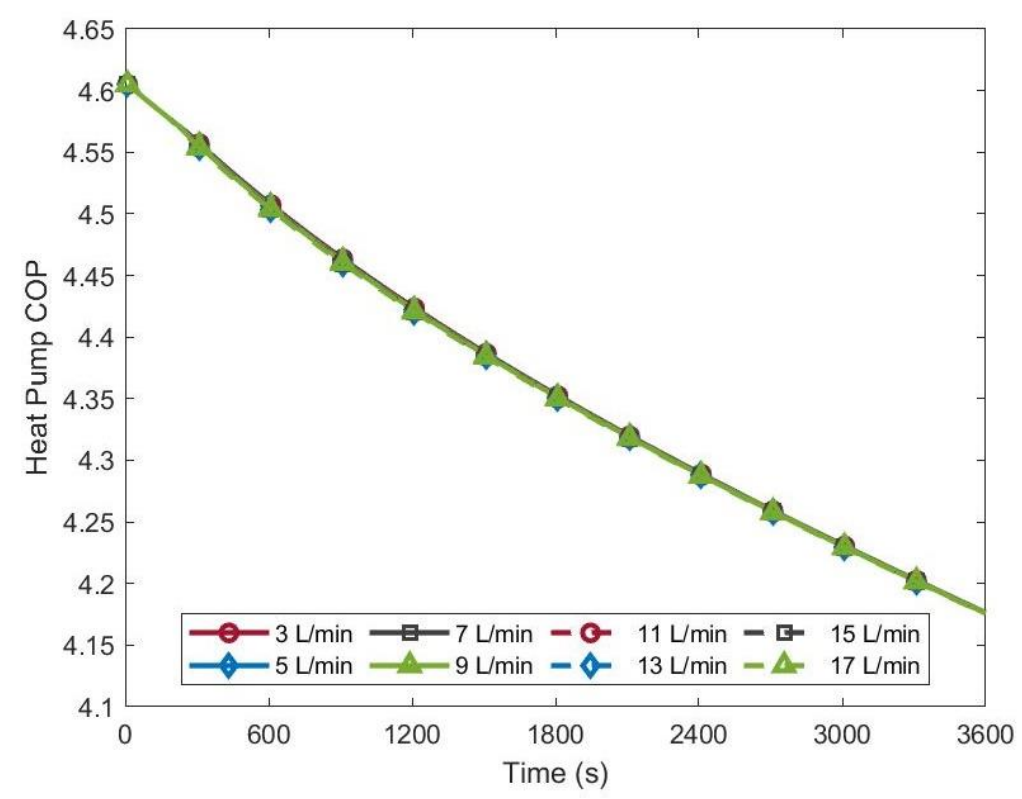

Figure 15: COP of the heat pump over time for different water flow rates with $I=750 \mathrm{~W} / \mathrm{m}^{2}$ and $V=50 \mathrm{~L}$.

328 Figure 16 represents the IEPVT/HP system's combined COP for different water flow rates over time. The variation of the PVT water flow rate does not have significant influence on the combined COP of the system. Because according to Equation (14) the combined COP is the sum of the heat pump COP, and the electricity produced divided by the compressor work. Additionally, Figure 15 showed that the water flow rate has no significant influence of the heat pump COP. In addition, for a fixed solar irradiation, Figure 12 shows that as the water flow rates increases from $3 \mathrm{~L} / \mathrm{min}$ to $17 \mathrm{~L} / \mathrm{min}$, the change in electrical efficiency is about $0.25 \%$. This means that the change in water flow rate has a very little influence on the amount of electrical power produced by the system. Therefore, there is no significant change in the system's combined COP with the change in water flow rate. 


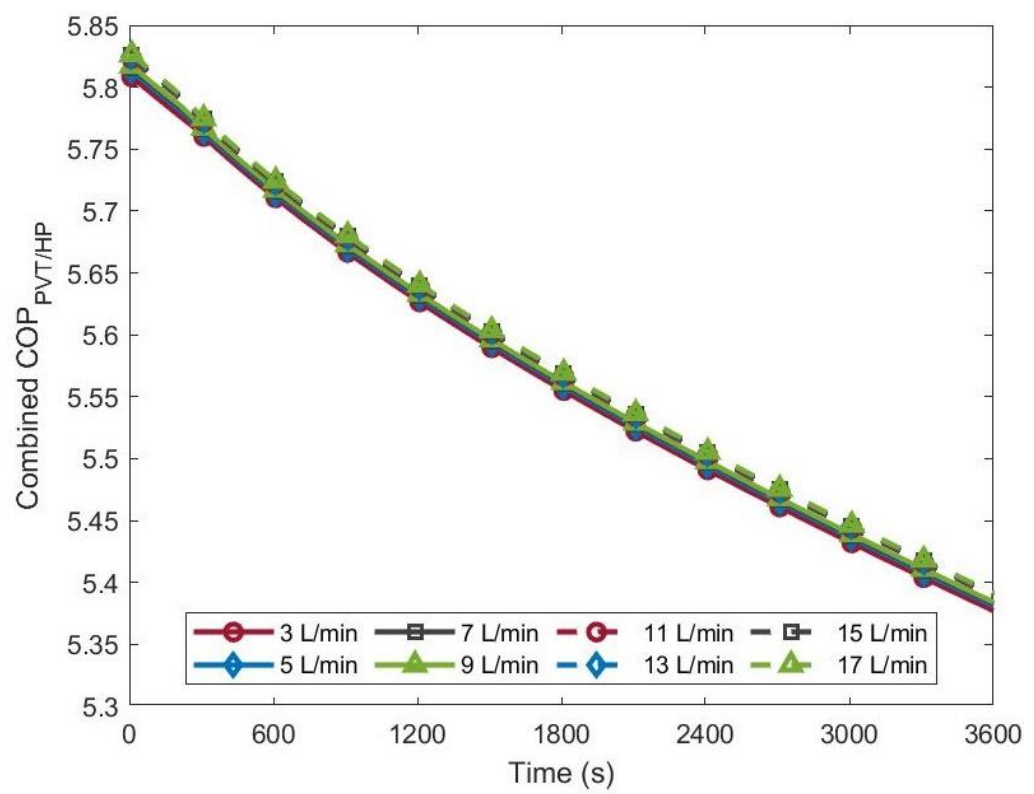

Figure 16: Combined COP of the PVT module and heat pump over time for different water flow rates with $I=750 \mathrm{~W} / \mathrm{m}^{2}$ and $V=50 \mathrm{~L}$.

\subsection{PVT Water Tank Volume}

In this section, the effect of volume variation in the PVT water tank on the performance of the system is analysed. The volume of the water tank studied is in the range of $V=[1 \mathrm{~L}-100 \mathrm{~L}]$, where 100L is approximately the tank size required for a family of four in the UK [8]. The solar irradiation intensity is fixed at $I=750 \mathrm{~W} / \mathrm{m}^{2}$ and the volumetric flow rate of the PVT cooling water is kept at $\dot{V}=5 \mathrm{~L} / \mathrm{min}$.

\subsubsection{Temperature Variation with PVT Water Tank Volume}

Figure 17 represents the change in PVT panel temperature for different PVT water tank volumes. The figure shows that for a fixed time as the volume of the tank increases, the temperature of the PVT panel decreases. However, the decrease in the PVT temperature is insignificant for high volume of the tanks. For example, at time $=3600 \mathrm{~s}$ the PVT temperature for the tank with $100 \mathrm{~L}$ is only $0.25^{\circ} \mathrm{C}$ lower than $1 \mathrm{~L}$ tank. Actually, for large volume of the tank (> 50L) the PVT temperature does not change significantly with time. According to Equation (15) for a large volume of water tank (high mass of water, $m_{w, \operatorname{tank}}$ ) the second term in the RHS of Equation (15) tends to zero. Therefore, the change in the tank temperature is zero (i.e. $T_{\text {tank,new }}=T_{\text {tank,old }}$ ), meaning that for large volumes of the tank, the water temperature in the tank remains almost constant $\left(\sim 14^{\circ} \mathrm{C}\right)$ during the system's operation. At the same time, the water tank is the supplier of cooling water to the PVT. Since, the tank temperature remains constant, the inlet temperature of the cooling water entering the PVT $\left(T_{i}\right)$ also remains constant. Hence, for a fixed solar irradiation and water flow rates, water temperature leaving the PVT $\left(T_{o}\right)$ as well as the PVT temperature remain constant for large volume of the water tank. 


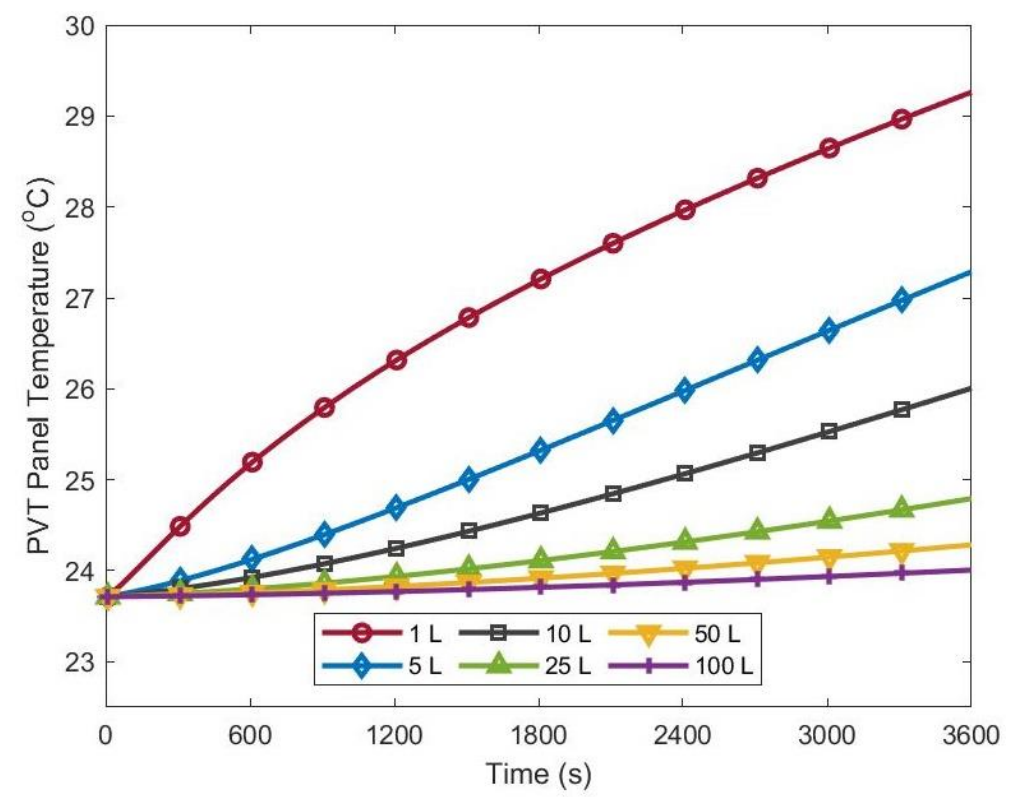

Figure 17: Temperature of the PV panel over time for different volumes of PVT water tank with $I=750 \mathrm{~W} / \mathrm{m}^{2}$ and $\dot{V}=5 \mathrm{~L} / \mathrm{min}$.

\subsubsection{Efficiency Variation with PVT Water Tank Volume}

Figure 18 represents the change in the total efficiency of the PVT for different PVT water tank volumes. The figure shows that for a large volume of the tank, the total efficiency remains almost constant at a value of $62.5 \%$ over time. Because, the total efficiency is the combination of thermal efficiency and electrical efficiency as given in Equation (12). Figure 19 shows that as the tank volume increase from $1 \mathrm{~L}$ to $100 \mathrm{~L}$ the drop in electrical efficiency over 3600 seconds reduces by $0.4 \%$ and $0.02 \%$, respectively. Additionally, as discussed for Figure 17, for a large volume of water tank the difference in water temperature entering and leaving the PVT (i.e. $T_{o}-T_{i}$ ) does not change for large tank volumes. Hence, the PVT thermal efficiency (Equation (10)) remains constant. Therefore, the total efficiency, which is the sum of electrical and thermal efficiencies, remains constant for large tank volumes as shown in Figure 18.

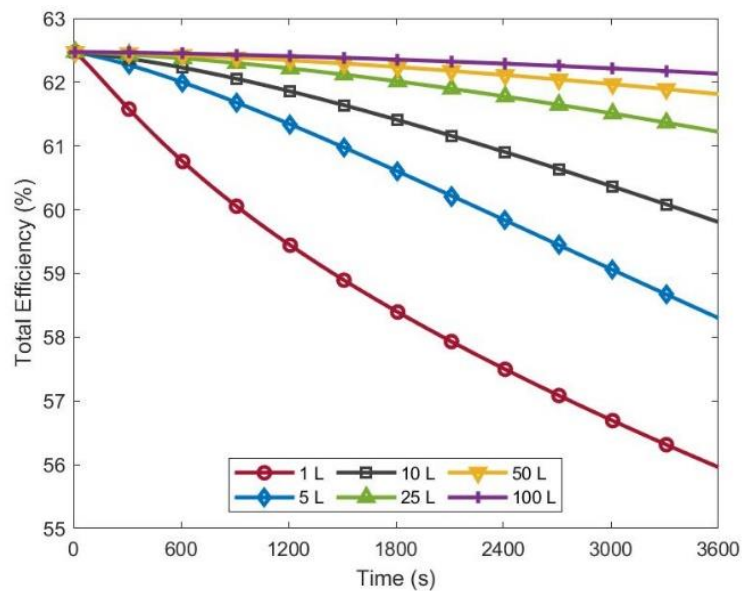

Figure 18: Total efficiency of the PVT over time for different water tank volumes with $I=750 \mathrm{~W} / \mathrm{m}^{2}$ and $\dot{V}=5 \mathrm{~L} / \mathrm{min}$.

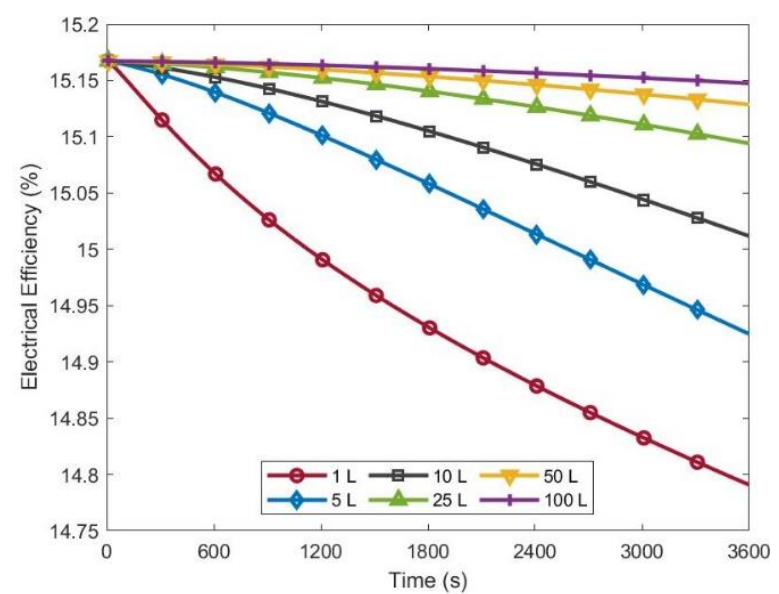

Figure 19: Electrical efficiency of the PVT over time for different water tank volumes with $I=750 \mathrm{~W} / \mathrm{m}^{2}$ and $\dot{V}=5 \mathrm{~L} / \mathrm{min}$. 


\subsubsection{Coefficient of Performance (COP) Variation with PVT Water Tank Volume}

Figure 20 graphs the change in the IEPVT/HP system's combined coefficient of performance (COP) for PVT water tank volumes. There is minimal change in the system's combined COP, with increasing PVT water tank volume. As discussed in Section 5.2.3, the main factor for increasing the combined COP, with a fixed speed heat pump, is to increase the electricity production of the PVT. Additionally, according to Figure 19, by changing the tank volume, the change in the electricity production is negligible in comparison to the heat production of the PVT. Hence, for fixed solar irradiation the electricity production does not significantly change with the tank volume. Therefore, the system's combined COP does not change significantly with the change of the tank volume.

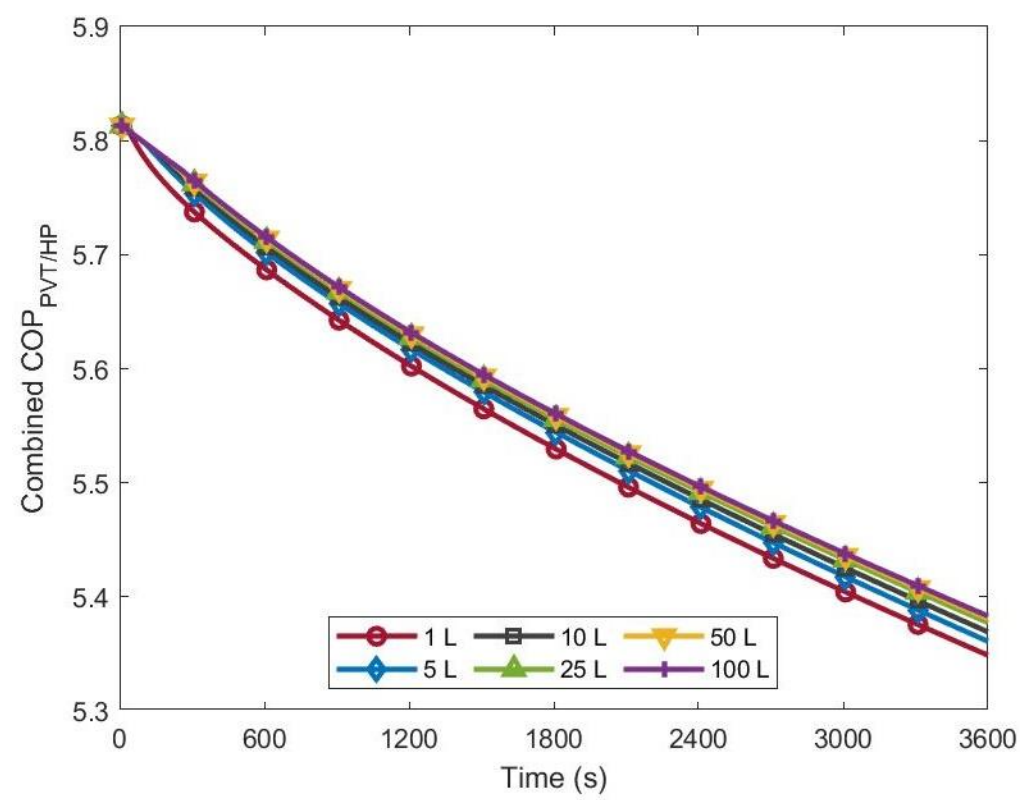

Figure 20: Combined COP of the PVT module and heat pump over time for different PVT water tank volumes with $I=750 \mathrm{~W} / \mathrm{m}^{2}$ and $\dot{V}=5 \mathrm{~L} / \mathrm{min}$.

\section{Conclusions and Further Discussion}

In this work, the thermal and electrical performance characteristics of a hybrid photovoltaicthermal heat pump system were studied using thermodynamic and heat transfer analysis. The study focused on the quasi-steady state modelling of an Indirect Expansion PVT Heat Pump (IEPVT/HP) configuration. The simulations demonstrated the system's transient performance characteristics for various solar irradiances, laminar and turbulent flow regimes in the PVT water pipe, and size of the water storage tank. The main findings of this work are as follows:

- Increasing the solar irradiation intensity (varied from $250 \mathrm{~W} / \mathrm{m}^{2}$ to $1000 \mathrm{~W} / \mathrm{m}^{2}$ ) results in increasing the PVT panel temperature from about $12^{\circ} \mathrm{C}$ to $30^{\circ} \mathrm{C}$ (i.e. $150 \%$ ). This temperature change results in a reduction of the electrical efficiency of the PVT panel, decreasing from $16.0 \%$ to $14.5 \%$. During the operation of the system, for the irradiation of $750 \mathrm{~W} / \mathrm{m}^{2}$ and $1000 \mathrm{~W} / \mathrm{m}^{2}$, the thermal efficiency decreases by $0.5 \%$ and $2 \%$ respectively. While for $250 \mathrm{~W} / \mathrm{m}^{2}$ and $500 \mathrm{~W} / \mathrm{m}^{2}$ the thermal efficiency increases over time, by $14 \%$ and $3.5 \%$, respectively. Increasing solar irradiation intensity (from $250 \mathrm{~W} / \mathrm{m}^{2}$ to $1000 \mathrm{~W} / \mathrm{m}^{2}$ ) raises the combined COP of the system by 1.2 , while it has negligible effect on the COP of heat pump only. 
- It is found that increasing the tank volume from $1 \mathrm{~L}$ to $100 \mathrm{~L}$ decreases the PVT temperature from $29^{\circ} \mathrm{C}$ to $24^{\circ} \mathrm{C}$ (i.e. $17 \%$ ). Additionally, increasing the water tank size from $1 \mathrm{~L}$ to $100 \mathrm{~L}$ increases the electrical and total (electrical and thermal) efficiencies of the PVT by $0.36 \%$ and $6.1 \%$, respectively. Variation in the tank size has negligible influence on the COP of the heat pump or the IEPVT/HP system as a whole.

- The PVT panel temperature found to decrease by $2.9^{\circ} \mathrm{C}$ when the PVT flow rates increased from $3 \mathrm{~L} / \mathrm{min}$ (laminar flow in the pipe) to $17 \mathrm{~L} / \mathrm{min}$ (turbulent flow). Increasing the flow rate, increases the electrical, thermal and total efficiencies of the PVT by $0.25 \%, 3.0 \%$ and $3.25 \%$, respectively, while it had no significant influence on the heat pump or combined COP of the system.

These results presented in this papers allow design considerations to be made based on the geographic location of the system due to expectations in solar irradiation availability in the region, the effect of which has now been documented in this work. Optimisation of the water flow rate into the PVT panel of the system and the extended effect it has on other areas of the system is shown to be needed in order to maximise total efficiency of the system. Future developments of alternative source or multi source heat pump systems can utilise the information provided and the trends shown to understand the influence solar sources can have in the overall system. The short-term simulation of the system allows for less generalisation of the performance over daily or weekly averaged results and allows observation of the transient effects that occur with changing variables. This will eventually contribute to the development of smarter, more intuitive control systems for the domestic energy generation control systems, specifically heat pump and solar energy integrated systems.

\section{Appendices}

\section{Appendix A: PVT Equations}

In this appendix, equations used to model the heat transfer through the PVT [30] are given. Radiative heat transfer coefficient between glass cover and the sky is:

$$
h_{r, g-s}=\frac{\varepsilon_{g} \sigma\left(T_{g}^{4}-T_{s}^{4}\right)}{\left(T_{g}-T_{a}\right)},
$$

where $T_{S}$ is the equivalent sky temperature expressed by:

$$
T_{s}=0.0552 T_{a}^{1.5} .
$$

Radiative heat transfer coefficient between glass cover and PV panel is obtained as:

$$
h_{r, p v-g}=\frac{\sigma\left(T_{g}^{2}+T_{p v}^{2}\right)\left(T_{g}+T_{p v}\right)}{\left(\frac{1}{\varepsilon_{g}}+\frac{1}{\varepsilon_{p v}}-1\right)} .
$$

Wind convection heat transfer coefficient calculated as:

$$
\begin{gathered}
h_{c, g-a}=3_{v_{w}}+2.8, \\
h_{c, a l-a}=\frac{k_{a l}}{d_{a l}}+\frac{1}{h_{c, g-a}} .
\end{gathered}
$$


426 Convective heat transfer coefficient of working fluid in pipe is given by:

$$
h_{w}=N u_{w} \frac{k_{w}}{D_{i}} .
$$

427 Nusselt number for thermally developing laminar flow inside the pipe is calculated as:

$$
N u_{w}=\left\{\begin{array}{cc}
1.953\left(x^{*}\right)^{-1 / 3} & x^{*} \leq 0.03 \\
4.364+\frac{0.0722}{x^{*}} & x^{*}>0.03
\end{array},\right.
$$

428 where $x^{*}$ is the expressed by:

$$
x^{*}=\frac{L}{\operatorname{RePr} D} .
$$

429 Nusselt number for turbulent flow is determined as:

$$
N u_{w}=\frac{(f / 8)(R e-1000) \operatorname{Pr}}{1+12.7(f / 8)^{1 / 2}\left(\operatorname{Pr}^{2 / 3}-1\right)} .
$$

431 Table A-1 contains heat transfer coefficients multiplied by area, i.e. ( $h d A)$.

Table A-1: Heat Transfer coefficient equations between PVT components.

\begin{tabular}{cc}
\hline Heat transfer between & Heat transfer coefficient multiplied by area \\
Glass - PV & $(h d A)_{p v-g}=\frac{k_{p v}}{\delta_{p v}} w d x$ \\
PV - Absorber & $(h d A)_{p v-a b s}=\frac{k_{a d}}{\delta_{a d}} w d x$ \\
Absorber - Pipe & $(h d A)_{a b s-t}=\frac{2 k_{a b s}}{w-D_{o}} \frac{\delta_{a b s}}{w} w d x$ \\
Pipe - Water & $(h d A)_{t-w}=\frac{1}{h_{w} \pi D_{i}}+\frac{w}{c_{b}}$ \\
Absorber - Glasswool & $(h d A)_{a b s-i g}=\frac{k_{i g}}{\delta_{i g}}\left(1-\frac{D_{o}}{w}\right) w d x$ \\
Tube - Glasswool & $(h d A)_{t-i g}=\frac{k_{i g}}{\delta_{i g}}(\pi+1) \frac{D_{0}}{w} w d x$ \\
Glasswool - EPS & $(h d A)_{i g-i p}=\frac{k_{i p}}{\delta_{i p}} w d x$ \\
EPS - Backplate & $($ A-11) \\
\hline
\end{tabular}




\section{Appendix B: Heat Pump Equations}

434 Equations used to model the four main components of the heat pump (compressor, condenser,

435 evaporator and expansion valve) are provided [34].

436 B.1. Compressor

437 Compressor modelled using Equations (B-1) to (B-7).

$$
\begin{gathered}
\dot{m}_{k}=\omega_{k} V_{k} \rho_{k} \eta_{k}, \\
\rho_{k}=f(P, h), \\
h_{k o}=h_{k i}+\frac{h_{k o, i s e n}-h_{k i}}{\eta_{i s e n}}, \\
h_{k o, i s e n}=f(P, s), \\
s_{k}=f(P, h), \\
\dot{Q}_{k}=\dot{m}_{k}\left(h_{k o}-h_{k i}\right), \\
\dot{W}_{k}=\frac{\dot{Q}_{k}}{\eta_{k}}=\frac{\dot{Q}_{k}}{\eta_{\text {mech }} \eta_{\text {elec }}} .
\end{gathered}
$$

438

\section{B.2. Condenser}

- Superheated and Two-Phase Stages

Superheated and two-phase heat transfer equations (Equations (B-8) to (B-15)) assume refrigerant in the condenser reaches two-phase state before exiting.

$$
\begin{gathered}
\dot{q}_{c}=\dot{m}_{r}\left(h_{r i}-h_{r o}\right), \\
\dot{q}_{c}=\dot{m}_{c, w} C_{p, w}\left(T_{c o, 1, w}-T_{c i, w}\right), \\
L M T D_{c}=\frac{\left(T_{r i}-T_{w o}\right)-\left(T_{r o}-T_{w i}\right)}{\ln \frac{\left(T_{r i}-T_{w o}\right)}{\left(T_{r o}-T_{w i}\right)}}, \\
\dot{q}_{c}=K_{c} F_{c} A_{c} L M T D_{c}, \\
K_{c}=\frac{1}{\frac{1}{h_{c, w}}+\frac{\delta_{c}}{k_{c}}+\frac{1}{h_{c, r}}}, \\
h=0.037\left(\operatorname{Re}^{4 / 5} \operatorname{Pr}^{1 / 3}\right) k / L_{c}, \\
\operatorname{Re}=\frac{\dot{m} D_{h}}{C S A \mu}, \\
\operatorname{Pr}, k, \mu=f(P, Q, T) .
\end{gathered}
$$

- Sub-cooled

Sub-cooling equations (Equations (B-16) to (B-22)) are included when the refrigerant reaches saturated liquid before exiting the condenser.

$$
\begin{gathered}
N T U=\frac{K_{c} F_{c} A_{c}}{C_{\min }}, \\
C=\frac{C_{\min }}{C_{\max }},
\end{gathered}
$$




$$
\begin{gathered}
\varepsilon=\frac{1-\exp ^{-N T U(1+C)}}{1-\left(\operatorname{Cexp}^{-N T U(1+C)}\right)} \\
\dot{q}_{c, \text { max }}=C_{\min }\left(T_{r i}-T_{w o}\right), \\
\dot{q}_{c}=\varepsilon \dot{q}_{c, \max }, \\
\dot{q}_{c}=\dot{m}_{w} C_{p_{w}}\left(T_{w o}-T_{w i}\right), \\
\dot{q}_{c}=\dot{m}_{r}\left(h_{r i}-h_{r o}\right) .
\end{gathered}
$$

448

450

451

452

453

454

\section{B.4. Evaporator}

Total heat transfer of the evaporator given by Equation (B-25).

$$
\dot{Q}_{e}=\dot{q}_{e, t w o-p h a s e}+\dot{q}_{e, \text { superheated }}
$$


458 A flowchart showing the details of the procedure used in the MATLAB code for solving the mathematical equations is given in Figure $\mathrm{C} 1$.

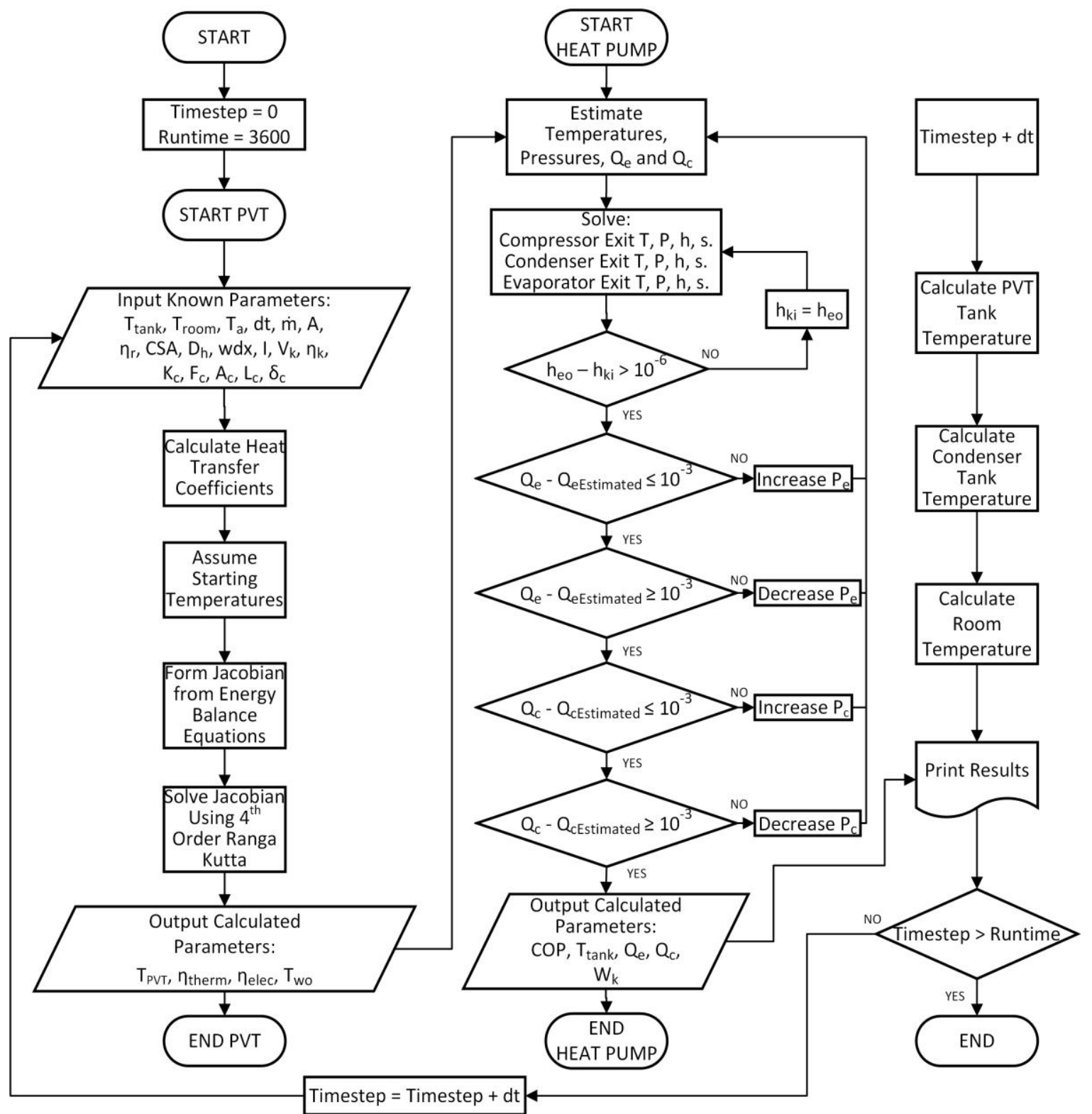

Figure $\mathrm{C} 1$ : Flowchart of the MATLAB modelling code for solving the mathematical equations

\section{References}

[1] A. Ramos, I. Guarrancino, A. Mellor, D. Alonso-Álvarez, P. Childs, N. J. Ekins-Daukes and C. N. Markides, "Solar-Thermal and Hybrid Photovoltaic-Thermal Systems for Renewable Heating," Grantham Institute, London, 2017.

[2] A. M. Omer, "Energy, environment and sustainable development," Renewable and Sustainable Energy Reviews, vol. 12, no. 9, pp. 2265-2300, 2008. 
[3] S. S. Joshi and A. S. Dhoble, "Photovoltaic-Thermal systems (PVT): Technology review and future trends," Renewable and Sustainable Energy Reviews, vol. 92, pp. 848-882, 2018.

[4] P. Dupeyrat, C. Ménézo and S. Fortuin, "Study of the thermal and electrical performances of PVT solar hot water system," Energy and Buildings, vol. 68, pp. 751-755, 2014.

[5] C. Rossi, L. A. Tagliafico, F. Scarpa and V. Bianco, "Experimental and numerical results from hybrid retrofitted photovoltaic panels," Energy Conversion and Management journal, vol. 76, pp. 634-644, 2013.

[6] D. Das, P. Kalita and O. Roy, "Flat plate hybrid photovoltaic- thermal (PV/T) system: A review on design and development," Renewable and Sustainable Energy Reviews, vol. 84, pp. 111-130, 2018.

[7] S. A. Kalogirou, "Photovoltaic Systems," in Solar Energy Engineering: Processes and Systems, Academic Press, 2014, pp. 481-540.

[8] M. Herrando, C. N. Markides and K. Hellgardt, "A UK-based assessment of hybrid PV and solarthermal systems for domestic heating and power: System performance," Applied Energy, vol. 122, pp. 288-309, 2014.

[9] M. Herrando and C. N. Markides, "Hybrid PV and solar-thermal systems for domestic heat and power provision in the UK: Techno-economic considerations," Applied Energy, vol. 161, pp. 512$532,2016$.

[10] N. Dai, X. Xu, S. Li and Z. Zhang, "Simulation of Hybrid Photovoltaic Solar Assisted Loop Heat Pipe/Heat Pump System," Applied Sciences, vol. 7, no. 2, p. 197, 2017.

[11] A. A. Ammar, K. Sopian, M. A. Alghoul, B. Elhub and A. M. Elbreki, "Performance study on photovoltaic/thermal solar-assisted heat pump system," Journal of Thermal Analysis and Calorimetry, vol. 136, pp. 79-87, 2019.

[12] H. Chen, S. B. Riffat and Y. Fu, "Experimental study on a hybrid photovoltaic/heat pump system," Applied Thermal Engineering, vol. 31, pp. 4132-4138, 2011.

[13] N. Khordehgah, V. Guichet, S. P. Lester and H. Jouhara, "Computational study and experimental validation of a solar photovoltaics and thermal technology," Renwable Energy, vol. 143, pp. 13481356, 2019.

[14] J. Ji, G. Pei, T.-t. Chow, K. Liu, H. He, J. Lu and C. Han, "Experimental study of photovoltaic solar assisted heat pump system," Solar Energy, vol. 82, no. 1, pp. 43-52, 2008.

[15] J. Zhou, X. Zhao, X. Ma, Z. Qiu, J. Ji, Z. Du and M. Yu, "Experimental investigation of a solar driven direct-expansion heat pump system employing the novel PV/micro-channels-evaporator modules," Applied Energy, vol. 178, pp. 484-495, 2016.

[16] L. Jia, W. Jin and Y. Zhang , "Analysis of Indoor Environment Safety with R32 Leaking from a Running Air Conditioner," Procedia Engineering, vol. 121, pp. 1605-1612, 2015.

[17] A. Fudholi, K. Sopian, M. H. Yazdi, M. H. Ruslan, A. Ibrahim and H. A. Kazem, "Performance analysis of photovoltaic thermal (PVT) water collectors," Energy Conversion and Management, vol. 78, pp. 641-651, 2014. 
[18] S. Harrison, "The Potential and Challenges of Solar Boosted Heat Pumps for Domestic Hot Water Heating," in 12th IEA Heat Pump Conference , Rotterdam, 2017.

[19] M. Ema, M. Naya, K. Yoshida and R. Nagaosa, "Reproductive and developmental toxicity of hydrofluorocarbons used as refrigerants," Reproductive Toxicology, vol. 29, no. 2, pp. 125-131, 2010 .

[20] N. Abas, A. R. Kalair, N. Khan, A. Haider, Z. Saleem and M. S. Saleem, "Natural and synthetic refrigerants, global warming: A review," Renewable and Sustainable Energy Reviews, vol. 90, pp. 557-569, 2018.

[21] A. Hazi and G. Hazi, "Comparative study of indirect photovoltaic thermal solar-assisted heat pump systems for industrial applications," Applied Thermal Engineering, vol. 70, no. 1, pp. 9099, 2014.

[22] G. Besagni, L. Croci, R. Nesa and L. Molimaroli, "Field study of a novel solar-assisted dualsource multifunctional heat pump,” Renewable Energy, vol. 132, pp. 1185-1215, 2019.

[23] M. Dannemand, B. Perers and S. Furbo, "Performance of a demonstaration solar PVT assisted heat pump system with cold buffer storage and domestic hot water storage tanks," Energy \& Buildings, Vols. 188-189, pp. 46-57, 2019.

[24] Y. Bai, T. T. Chow, C. Ménézo and P. Dupeyrat, "Analysis of a Hybrid PV/Thermal SolarAssisted Heat pump System for Sports Center Water Heating Applications," International Journal of Photoenergy, vol. 2012, 2012.

[25] A. Zarrella, G. Emmi, J. Vivian, L. Croci and G. Besagni, "The validation of a novel lumped parameter model for photovoltaic thermal hyvrid solar collectors: a new TRNSYS type," Energy Conversion and Management, vol. 188, pp. 414-428, 2019.

[26] P. Das, J. Mathur, R. Bhakar and A. Kanudia, "Implications of short-term renewable energy resource intermittency in long-term power system planning," Energy Strategy Reviews, vol. 22, pp. 1-15, 2018.

[27] I. H. Bell, J. Wronski, S. Quoilin and V. Lemort, "Pure and Pseudo-pure Fluid Thermophysical Property Evaluation and the Open-Source Thermophysical Property Library CoolProp," Industrial \& Engineering Chemical Research, vol. 53, no. 6, pp. 2498-2508, 2014.

[28] E. W. Lemmon, I. H. Bell, M. L. Huber and M. O. McLinden, "NIST Standard Reference Database 23: Reference Fluid Thermodynamic and Transport Properties-REFPROP, Version 10.0, National Institute of Standards and Technology," National Institute of Standards and Technology, Gaithersburg, 2013.

[29] T. T. Chow, "Performance analysis of photovoltaic-thermal collector by explicit dynamic model," Solar Energy, vol. 75, no. 2, pp. 143-152, 2003.

[30] F. Yazdanifard, E. Ebrahimnia-Bajestan and M. Ameri, "Investigating the performance of a water-based photovoltaic/thermal (PV/T) collector in laminar and turbulent flow regime," Renewable Energy, vol. 99, pp. 295-306, 2016.

[31] Solimpeks Solar Energy Corp., "Volther PowerVolt," Solimpeks Solar Energy Corp., 20018. [Online]. Available: http://www.solimpeks.com/volther-powervolt-en. [Accessed 3 June 2019]. 
[32] S. Sami, "Modeling and Simulation of a Novel Combined Solar Photovoltaic-Thermal Panel and Heat Pump Hybrid System," Clean Technologies, vol. 1, pp. 89-113, 2018.

[33] C. Rossi, M. De Rosa, V. Bianco, F. Scarpa and L. A. Tagliafico, "Comparison between different photovoltaic solar-assisted heat pumps (PVT-SAHP) configurations with retrofitted photovoltaic panels," WSEAS Transactions on Environment and Development, vol. 10, pp. 329-340, 2014.

[34] F. Fardoun, O. Ibrahim and A. Zoughaib, "Quasi-Steady State Modeling of an Air Source Heat Pump Water Heater,” Energy Procedia, vol. 6, pp. 325-330, 2011.

[35] B. J. Huang, T. H. Lin, W. C. Hung and F. S. Sun, "Performance evaluation of solar photovoltaic/thermal systems," Solar Energy, vol. 70, no. 5, pp. 443-448, 2001.

[36] U. Camdali, M. Bulut and N. Sozbir, "Numerical modeling of a ground source heat pump: The Bolu case," Renewable Energy, vol. 83, pp. 352-361, 2015.

[37] h. I. Abu-Mulaweh, "Development and performance validation of portable air-conditioning experimental apparatus," International Journal of Mechanical Engineering Education, vol. 37, no. 2, pp. 144-158, 2012.

[38] Yr.no, "Weather Statistics for Belfast, Northern Ireland (United Kingdom)," Norwegian Meteorological Institute, $2019 . \quad$ [Online]. Available: https://www.yr.no/place/United_Kingdom/Northern_Ireland/Belfast/statistics.html. [Accessed 3 June 2019].

[39] C. Zhou, R. Liang, J. Zhang and A. Riaz, "Experimental study on the cogeneration performance of roll-bond-PVT heat pump system with single stage compression during summer," Applied Thermal Engineering, vol. 149, pp. 249-261, 2019.

[40] Energy Saving Trust, "Measurement of Domestic Hot Water Consumption," Department for Environment, Food and Rural Affairs, 2008.

[41] R. Saab, H. Al Quabeh and M. I. H. Ali, "Variable refrigerant flow cooling assessment in humid environment using different refrigerants," Journal of Environmental Management, vol. 224, pp. 243-251, 2018.

[42] A. Gagliano, G. M. Tina, F. Nocera, A. D. Grasso and S. Aneli, "Description and performance analysis of a flexible photovoltaic/thermal (PV/T) solar system," Renewable Energy, vol. 137, pp. 144-156, 2019.

[43] A. Belghachi, "Theoretical Calculation of the Efficiency Limit for Solar Cell," in Solar Cells, Rijeka, IntechOpen, 2015, pp. 47-76.

[44] A. De Vos, "Detailed balance limit of the efficiency of tandem solar cells," Journal of Physics D: Applied Physics, vol. 13, pp. 839-846, 1980.

[45] R. Brendel, J. H. Werner and H. J. Queisser, "Thermodynamic efficiency limits for semiconductor solar cells with carrier multiplication," Solar Energy Materials and Solar Cells, Vols. 41-42, pp. 419-425, 1996.

[46] H. Chen, L. Zhang, P. Jie, Y. Xiong, P. Xu and H. Zhai, "Performance study of heat-pipe solar photovoltaic/thermal heat pump system," Applied Energy, vol. 190, pp. 960-980, 2017. 
[47] X. Wu, "Theoretical Analysis and Experimental Study on the PV-IESAHP System," in AIP Conference Proceedings, 2017.

462

463 